\title{
Bank Audit Fees and Asset Securitization Risks
}

SUMMARY: We examine whether bank auditor effort, proxied by audit fees, is related to asset securitization risks (ASR) and whether the incremental auditor effort attributed to ASR is related to audit quality. Our sample period encompasses the Global Financial Crisis (GFC) and the introduction of FAS No. 166 and FAS No. 167, which were intended to constrain accounting for asset securitizations as sales. Using U.S. bank holding company (BHC) data from 2003 to 2013, we find significantly positive associations between ASR and audit fees for Big N auditors but not for non-Big $\mathrm{N}$ auditors. Pre-GFC audit fees have a positive association with ASR, and are more significant for BHCs reporting a loss. After the implementation of FAS Nos. 166 and 167, this positive association persists, mainly driven by BHCs reporting a loss. With respect to the incremental auditor effort attributed to ASR, we find that, prior to the GFC, the incremental audit effort by Big $\mathrm{N}$ auditors, but not by non-Big $\mathrm{N}$ auditors, reduced the likelihood of subsequent restatements and constrained reported gains on securitizations.

Keywords: audit fees; asset securitization risks; bank holding companies; financial crisis; restatements; securitization gains.

JEL Classification G14, G21, M42 


\section{INTRODUCTION}

The securitization market was a primary factor in the global financial crisis (GFC) (Solomon 2012). Banks were key players in the asset securitization market, and the source of many of the securities backed by mortgage loans. A conservative estimate by the Financial Times early in the GFC was that banks had moved around US\$5 trillion in assets and liabilities off balance sheet (Sikka 2009) and Barth, Ormazabal, and Taylor (2012) report that, on average, securitized assets made up $20 \%$ of banks' total assets. Perhaps more importantly, large banks were the dominant originators of securitization transactions. Barth et al. (2012) report that the median size of the securitizing banks was more than $\$ 40$ billion in assets. The exposure of major financial institutions to the risks arising from the securitization of mortgages was exposed with the bursting of the housing bubble in 2006. The downturn in the U.S. property market escalated the rate of mortgage defaults, spurred the burgeoning credit crisis, squeezed the earnings of financial sector businesses and reduced confidence in the banking sector. Deteriorating corporate earnings, the fragility of subprime debt instruments and liquidity issues caused an exodus of deposits that led to prominent bank failures. These factors, combined with the accompanying demise of other financial entities crucial to the shadow banking system, had substantial flow-on effects that led to the onset of the GFC.

Subprime mortgage problems that emerged through 2003-2005 and related prosecutions in 2006 led to substantial public and political attention to accounting issues pertaining to asset securitizations (e.g., Karaoglu 2005; Niu and Richardson 2006; Schipper and Yohn 2007). The focus on accounting was evident in media coverage; for example, "[a] big part of the problem is that accounting rules have allowed banks to inflate the value of their assets. Accounting has become a new exercise in creative fiction, with the result that banks are carrying a lot of 'sludge' 
assets clogging up the balance sheet" (Giannone and Davies 2008). Criticisms of the auditing of securitizations of mortgage-backed securities and collateralized debt obligations intensified with the 2007 surge in problems in asset securitizations faced by financial institutions and was aggravated by subsequent high-profile failures of banks and other mortgage lenders (Sikka 2009). Allegedly, auditors used inadequate audit processes and issued inappropriate opinions on banks with significant securitization risks and overall insolvency issues (Sikka 2009). ${ }^{1}$ Auditors were also accused of aiding GAAP violations (Palepu, Srinivasan, and Sesia 2009). ${ }^{2}$

To the best of our knowledge, no prior research has examined auditor responses to asset securitization risks (ASR) and whether this is associated with audit quality, the impact of the GFC or the introduction of FAS No. 166 and FAS No. 167 in this regard. We address these substantial gaps in our knowledge of bank audits and related policy concerns by examining the relation between ASR risks and audit fees. ${ }^{3}$ We also extend the literature by examining whether the incremental audit effort attributable to ASR affects audit quality, as proxied by earnings restatements and securitization gains. In addition, we investigate whether these relations changed as public concerns about the relevant risks increased during the GFC and whether subsequent regulatory restrictions on accounting treatments reduced misstatement risks, as reflected in the

1 Although auditors are not required to predict business failures, market participants anticipate predictive information from auditors' reports (Knechel, Krishnan, Pevzner, Bhaskar, and Velury 2013). Therefore, the extent to which auditors identify forward-looking risk factors is critical to enhancing market-expectations of audit quality.

2 Examples of the cases related to asset securitization scandals and auditing irregularity include Fannie Mae in 2006 (OFHEO 2006), Lehman Brothers in 2007 (Wiggins, Bennett, and Metrick 2014) and New Century in 2007 (Palepu et al. 2009). Accusations that New Century's auditor, KPMG, failed to take appropriate action and aided in breaches of GAAP are contained in the Complaint for Declaratory Relief; Negligence and Aiding and Abetting Breach of Fiduciary Duty to the Superior Court of The State of California filed by Thomas, Alexander \& Forrester LLP (attorneys for The New Century Liquidating Trust) in March 2009.

3 Prior studies find that increases in audit fees are at least partly or almost exclusively due to higher levels of auditor effort, rather than to a pure risk premium (e.g., Lobo and Zhao 2013; Schelleman and Knechel 2010; Simunic and Stein 1996). 
attendant audit fees and our measures of audit quality. If auditors responded to differences in ASR by adjusting their audit effort, we should observe positive associations between ASR and audit fees. If auditors' responses were appropriate, audit fees attributable to ASR should be positively related to audit quality.

Historically, management's discretion in accounting for asset securitizations allowed risks to be moved off-balance sheet. While prior studies find that audit fees are positively related to the risks and complexity of bank audits (Fields, Fraser, and Wilkins 2004, Boo and Sharma 2008, Ettredge, Xu, and Yi 2014b, Doogar, Rowe, and Sivadasan 2015), there is no prior research into whether audit fees reflect off-balance sheet financial risks; these are more challenging for auditors to identify than on-balance sheet financial risks and often arise from more-complex transactions. We extend the bank audit literature by examining the effects of both on-balance sheet and off-balance sheet ASR on audit effort. ${ }^{4}$

The expected relations between audit effort, ASR and audit quality are not obvious and may have changed over time. The GFC onset in 2007 is associated with substantial financial distress in the banking sector and banks' asset securitization activities; these may have increased auditors' sensitivity to ASR, with an associated increase in audit fees. ${ }^{5}$ The complexity of asset securitizations and management's flexibility in sales or borrowings accounting (Kane 1997; Schipper and Yohn 2007) may have impeded auditors in identifying and evaluating the economic

4 Doogar et al. (2015) document annual audit pricing changes relative to residential mortgage loan origination, distribution and investment in the lead-up to the GFC and focus on mortgage related retained interests and ignore off-balance sheet risks. We examine on- and off-balance sheet risks and income statement risks arising from asset securitizations, and include other types of loans besides residential mortgage loans. In addition to retained interests, we explore risks for the overall magnitude of the securitization activities, securitization income, and underlying quality of securitized assets.

5 Hill, Ramsay, and Simon (1994) find bank audit fees were sensitive to banks' business failure risks during the savings and loan crisis of the 1980s and 1990s, but examined within-period relations only and not whether sensitivities changed from the onset or development of the crisis. 
substance of the instruments, the financial risks for the originating bank, and the accompanying opportunities for earnings and capital management manipulations (Healy and Wahlen 1999; Matsumoto 2002; Karaoglu 2005).

In addition to the adequacy of auditors' responses to ASR, there are policy concerns as to whether related regulatory responses were effective. In 2009, FAS No. 166 and FAS No. 167 were issued to constrain financial institutions' use of sales accounting and non-consolidation of asset securitizations (Financial Accounting Standards Board 2009c). ${ }^{6}$ Although securitization transactions may remain a source of misstatement risk, the constraints imposed by FAS Nos. 166 and 167 from 2010 reduced the complexity of accounting treatments and largely eliminated opportunities for related accounting manipulations. This should have reduced misstatement risk and audit effort, thus reducing the impact of asset securitization risks on audit fees. Therefore, we investigate whether audit fee sensitivity to ASR changed, first as a result of the GFC and then as a consequence of FAS Nos. 166 and 167.

Using publicly available U.S. bank holding company (BHC) data through 2003-2013, we examine auditor sensitivity to ASR. We test a securitization risk measure obtained from a principal components factor analysis (similar to Cheng, Dhaliwal, and Neamtiu 2011) of the ratios of securitized assets to total assets, retained interests to total assets, non-performing securitized loans to total assets, charge-offs for securitized loans to total assets, and gains from securitizations to total revenue, and the individual risk measures. We find that Big $\mathrm{N}$ auditors are sensitive to the risks associated with asset securitization transactions, and this sensitivity varies systematically with changes in economic and regulatory environments. Pre-GFC, audit fees are

6 Financial Accounting Statements No. 166, Accounting for Transfers of Financial Assets, and No. 167, Amendments to FASB Interpretation No. 46(R). 
sensitive to ASR and this sensitivity is much greater for BHCs reporting losses. During the GFC, audit fees become more sensitive to BHC losses, which results in ASR being less relevant, such that the positive impact of ASR on audit fees persists only for non-loss BHCs. From 2010, when GFC concerns were waning and the implementation of new accounting standards constrained management opportunities to manipulate accounting treatments, audit fees are sensitive to ASR only for BHCs reporting losses; there is no significant effect of ASR on audit fees for non-loss firms. We did not find a significant relation between ASR and audit fees for non-Big N auditors.

Additional analyses suggest that auditors are sensitive to, and constrain, potential accounting manipulations when reviewing asset securitizations. This sensitivity generally increases when banks face the financial stress associated with losses. Our examination of the relations between audit fees and the use of discretionary loan loss provisions and going-concern opinions suggests that the increased audit effort in relation to misstatement risks and asset securitization complexity, rather than the possibility of business failure, is more likely to be the main reason for the ASR-audit fee association. This is supported by our evidence that, prior to the GFC, the additional audit effort attributed to asset securitization risks for Big $\mathrm{N}$ auditors reduced the likelihood of subsequent restatements and constrained reported gains on securitizations. We do not find a significant relation for non-Big $\mathrm{N}$ auditors. As indicated by the change in relations between ASR and audit fees during the GFC, when business failures increased, it appears that financial distress become such a more pervasive risk concern for Big $\mathrm{N}$ auditors, such that securitisation risks did not have a significant additional impact on risk assessments for BHCs reporting a loss but remained relevant for BHCs reporting profits.

Our study makes important contributions with substantial policy relevance. It responds to the call by the Basel Committee on Bank Supervision (2008) for more research into bank audits 
and contributes to the literature on bank audits, which is a continuing area of interest for bank regulators and market participants. The evidence that Big $\mathrm{N}$ auditors responded effectively to ASR, and that their behavior changes in response to changes in market and regulatory conditions, suggests that Big $\mathrm{N}$ auditors did consider securitization risks when conducting bank audits. Our findings contribute to the resolution of the debate as to whether, prior to the GFC, auditors dealt adequately or appropriately with banks' significant securitization risks (e.g., Sikka 2009; Palepu et al. 2009). We find that, prior to the GFC, Big N auditor effort attributed to ASR reduced the likelihood of subsequent restatements and constrained reported securitizations gains. This suggests that Big $\mathrm{N}$ auditor effort in relation to ASR had a positive impact on audit quality prior to the increased public scrutiny of banks' asset securitization activities that accompanied the GFC. We do not find that non-Big N auditors responded significantly to ASR and or that non-Big $\mathrm{N}$ auditor incremental effort in response to ASR improved audit quality.

The remainder of this paper is organized as follows. We next describe salient features of the securitization of banks' financial assets and review the relevant research, followed by our hypotheses development. We then present our research design and provide our main results. We report robustness tests and additional analyses relating audit effort and asset securitization risks to the potential accounting manipulations, before presenting our conclusions.

\section{SECURITIZATIONS OF BANKS’ FINANCIAL ASSETS}

\section{The Securitization Process}

A bank's asset securitization transaction begins with the bank selling its cash flow rights from a pool of financial assets, such as mortgages and other loans, to a special purpose entity (SPE), which was usually organized as a 'qualifying special purpose entity' (QSPE) to avoid 
consolidation in the bank's accounts. The SPE then securitizes the assets in tranches that are graded by rating agencies. In the absence of credit enhancements, the most junior securities tranche is the first to bear any default losses and, when this tranche is exhausted, losses pass to the second junior tranche, and so on, until all losses are absorbed. Credit enhancements can further insulate senior securities from the default risk on the underlying financial assets. Enhancements are provided by the originators or a third-party guarantor in the form of cash collateral accounts, reserve funds, commitments to (re)purchase assets in default, credit derivatives or recourse provisions.

The usual securitization strategy maximizes the size of the most senior tranche while still obtaining a AAA rating and leaves the most junior tranche unrated and as small as possible while still allowing the second tranche to obtain an investment-grade rating (Ryan 2008). The investment-grade tranches are sold to investors and the most junior tranche is usually retained by the SPE. Proceeds from investors fund the SPE's purchase of the cash flow rights from the bank. The SPE distributes the future cash flows generated by the underlying securitized assets to the investors, as specified in the security.

\section{Accounting Choices for Securitization Transactions}

A bank's main accounting choice in relation to the securitization of financial assets is whether the transfer of its cash flow rights to the SPE is treated as a sale or as a borrowing. Asset securitizations that are treated as sales are not reflected on the balance sheet, although these transactions may still expose banks to default or recourse risks (Beatty and Liao 2014). From 2003 to 2009, the choice between accounting for a securitization as a sale or as a borrowing was 
permitted under FAS No. 140 (2003 to 2006) or FAS No. 156 (after 2006) and FIN No. 46(R). ${ }^{7}$

From November 2009, FAS Nos. 166 and 67 constrained accounting choices with respect to treatment of asset securitizations as a sale and the use of non-consolidated QSPEs.

Appendix 1 Panel A presents exemplar accounting procedures for an asset securitization transaction under FAS 140, FAS 156 and FAS 166 (adapted from Dechow and Shakespeare 2009). Treating a transaction as a sale under FAS No. 140 or FAS No. 156 allowed a bank to: (1) remove the securitized assets from its balance sheet; (2) record cash received plus the fair value of non-cash proceeds as a sale; (3) recognize the book value of the retained sub-securities as a proportion of the fair value of the securitized assets; (4) value the retained interests in securitized assets (e.g., servicing assets) in the same way as retained sub-securities under FAS No. 140 or at fair value under FAS No. 156; and (5) record the difference between sales proceeds and the value of the components of assets sold as a securitization gain or loss (Cheng et al. 2011). ${ }^{8}$ The sale accounting and non-consolidation of the SPE as allowed by FAS Nos. 140 and 156 and FIN 46R provide accounting benefits to the originating bank, as displayed in Appendix 1 Panel B. These include a lower leverage ratio, a better liquidity ratio, higher profitability and (possibly) a more favourable risk-based capital ratio.

7 The change from FAS No. 140 Transfers and Servicing of Financial Assets and Extinguishments of Liabilities to FAS No. 156 Accounting for Servicing of Financial Assets an Amendment of FASB Statement No. 140 had a very limited impact on the sale versus borrowing accounting choice. The required change of fair value measurement to servicing assets in FAS No. 156 does not have a substantial effect in our study because servicing assets represent a small portion of retained interests and retained interests are not central to our study. FIN No. 46(R) is FASB Interpretation No. 46 Consolidation of Variable Interest Entities an interpretation of ARB No. 51.

8 For a securitization to qualify as a sale, the transferor must transfer the financial assets to a bankruptcy-remote entity and surrender control of the transferred assets. To avoid being included in the bank's consolidated financial report, the entity must be a QSPE satisfying the conditions specified in FIN No. 46(R), or otherwise independent of the bank. If the asset transfer qualifies as a sale, the loans are taken off the balance sheet and the bank recognizes any retained interests (including servicing assets) on its balance sheet; unrealized future cash flows are treated as a gain or loss in the current income statement. Compared with secured borrowing accounting, sale accounting has the effect of dressing up reported leverage, liquidity, earnings, and the capital ratio. 
For financial years commencing after November 2009, FAS Nos. 166 and 167 constrained accounting choices by removing the concept of a QSPE and the associated consolidation exemption. These standards also introduced the "continuing involvement" and "participating interest" criteria, whereby entitlements to cash flows correspond to shares of ownership. Continuing recognition is required if the bank has continued involvement with the transferred assets; and all assets (including retained interests) and liabilities arising from a securitization transaction that is accounted for as a sale are required to be initially recorded at fair value. These changes removed many off-balance sheet risks associated with asset securitizations.

\section{The Economic Substance of Asset Securitizations}

A fundamental risk issue in asset securitizations is the explicit or implicit recourse that leaves the originator with residual risks in addition to their recognized retained interests. Before the FAS Nos. 166 and 167 reformations, asset securitizations could be treated as sales with the associated transfers of risks under FAS No. 140 and FIN No. 46(R). Although rating agencies asserted that they treated asset securitizations as secured borrowings before and after the subprime crisis (e.g., S\&P Corporate Rating Criteria 2001, 2008), empirical evidence suggests that they treated asset securitizations as sales (Cheng and Neamtiu 2009; Barth et al. 2012). In contrast, capital market responses suggest investors viewed asset securitizations as secured borrowings (Treacy and Carey 1998; Niu and Richardson 2006; Schipper and Yohn 2007; Chen, Liu, and Ryan. 2008; Landsman, Peasnell, and Shakespeare 2008; Barth et al. 2012).

Limited disclosures during 2003-2009 that constrain identification of originating banks' recourse risks and flexibility in accounting treatments exacerbated information asymmetry and uncertainty (Barth, Clinch, and Shibano 2003) arising from the complexity of securitization 
transactions, procedures and documentation (Schwarcz 2004; Ryan 2007). Although FAS Nos. 166 and 167 reduced accounting flexibility after 2009, information uncertainty persists.

\section{HYPOTHESES DEVELOPMENT}

\section{Asset Securitization Risks and Audit Fees}

Auditors are expected to respond to risks of material misstatement by allocating more resources to the relevant risk areas, thus increasing audit fees (Hay, Knechel, and Wong 2006). ${ }^{9}$ Asset securitization transactions are expected to increase auditors' assessed risks of material misstatements because of the complexity of accounting treatments, the legal complexities of asset securitizations involving multiple parties (e.g., the client bank, one or more SPEs, a guarantor, a rating agency and investors) and opportunities to manipulate earnings through the recognition of securitization gains and losses. Accounting for a securitization as a sale and externalization of the SPE and its transactions under FAS No. 140 may veil the economic substance of transactions and the financial risk to the bank. This concern can be more acute when a bank has incentives to manipulate financial performance and/or capital levels (Healy and Wahlen 1999; Degeorge, Patel, and Zeckhauser 1999; Matsumoto 2002; Karaoglu 2005). There is evidence that banks opportunistically used asset securitizations to manipulate earnings or capital levels by discretionary choices in the timing of securitization transactions (Dechow and Shakespeare 2009), the classification of transactions as sales vs. borrowings (Karaoglu 2005), selection of loans to be securitized (Pavel and Phillis 1987; Ambrose, LaCour-Little, and Sanders 2005), and

9 Alternatively, if additional audit effort will not produce sufficient appropriate evidence to reduce audit risk to an acceptable level, higher audit fees may be charged as compensation for potential litigation risk or reputation loss (Simunic and Stein, 1996). 
the valuation of retained interests (Dechow, Myers, and Shakespeare 2010). There is experimental evidence of the positive impact of the risk of earnings management or aggressive financial reporting on audit planning and pricing (e.g., Houston, Peters and Pratt 1999; Phillips 1999; Beaulieu 2001) and archival research (e.g., Gul, Chen, and Tsui 2003; Bedard and Johnstone 2004; Lyon and Maher 2005). Therefore, we argue that ASR will increase auditors' assessed risks of material misstatements and auditors will adjust their audit effort accordingly. On this basis, we hypothesize a positive association between ASR and audit fees:

H1: There is a positive association between ASR and audit fees.

\section{The GFC and Asset Securitization risks}

The exposure of major financial institutions to the risks arising from the securitization of mortgages was highlighted with the downturn in the U.S. property market, which escalated the rate of mortgage defaults. Deteriorating corporate earnings, the fragility of subprime debt instruments and liquidity issues caused an exodus of deposits that led to prominent bank failures. These factors, combined with the accompanying demise of other financial entities crucial to the shadow banking system, had substantial flow-on effects that led to the onset of the GFC. The GFC was a significant economic shock that had substantial implications for asset values and business risks in the banking sector. Throughout 2003-2006, the business bankruptcy filings were relatively stable at around 35,000 filings in each year. Filings dipped to 25,925 in 2007 and then surged to 58,721 in 2009 and 56,282 in $2010 .^{10}$ It is likely that the increased systemic risks that arose with the onset of the GFC, accompanied by the associated solvency, constraints on the

10 Bankruptcy statistics were obtained from www.uscourts.gov/statistics. A similar pattern is observed for non-business bankruptcy filings, which went from 597,965 in 2006 to 1,536,799 in 2010. 
availability of capital and credit, and the liquidity issues would have further sensitized auditors to asset securitization concerns.

Given the prominence of asset securitizations in relation to the subprime crisis and the subsequent GFC, irrespective of auditors' awareness of changes at the engagement level and the risks associated with asset securitizations pre-GFC, it is plausible that auditors paid more attention to ASR following the onset of the GFC, resulting in a stronger relation between audit fees and ASR. ${ }^{11}$

H2: The positive association between ASR and audit fees is stronger after the onset of the GFC compared to before the GFC.

However, the effect of the GFC on the relation between ASR and audit fees may not be observed if the GFC had a negative effect on audit fees, as reported by Ettredge, Emeigh, and Li (2014a) and Krishnan and Zhang (2014). However, these studies did not distinguish banks with asset securitizations and there is no evidence that audit fee pressure would negate the impact of securitization risks on audit planning and pricing.

\section{The Impact of FAS No. 166 and FAS No. 167 on Asset Securitization Risks}

Following the subprime crisis and the GFC, and at the request of investors, the SEC and The President's Working Group on Financial Markets, FAS Nos. 166 and 167 were proposed to "improve existing standards and to address concerns about companies who were stretching the

11 Following NBER (2010), we use 2007 as the GFC cut-off and treat 2007-2009 as the 'during-GFC period'. The recent widespread interest in auditors' responsibility for reporting on the going-concern status of their financially troubled clients arises from the GFC. The GFC began in late 2007 when, among other events, mounting losses on subprime mortgages triggered substantial disruptions in the U.S. financial system, and, given the interconnectedness of international business, these financial shocks quickly spread around the globe. The GFC officially ended in the U.S. in June of 2009 (NBER 2010). 
use of off-balance sheet entities to the detriment of investors". ${ }^{12}$ In January 2008, the SEC asked the FASB to prioritize its efforts to address the accounting for off-balance sheet arrangements. ${ }^{13}$

The implementation of FAS Nos. 166 and 167 in November 2009 substantially reduced misstatement risks related to asset securitizations. This is emphasized by Robert Herz, chairman of the FASB, in a press release announcing the issue of the new standards in 2009: "The new standards eliminate existing exceptions, strengthen the standards relating to securitizations and special-purpose entities, and enhance disclosure requirements. They'll provide better transparency for investors about a company's activities and risks in these areas." ${ }^{\prime 4}$ In contrast to the earlier practice of sale accounting and non-consolidation, FAS Nos. 166 and 167 eliminated QSPEs and the associated consolidation exemption and introduced the "continuing involvement" and "participating interest" criteria, whereby balance sheet recognition is required if the bank has continuing involvement with the transferred assets and all assets (including retained interests) and liabilities arising from a securitization transaction that is accounted for as a sale must be initially recorded at fair value. Therefore, we expect that auditors' concerns with misstatement risk, and thus the relations between audit pricing and asset securitization risks, will decline following the implementation of FAS Nos. 166 and 167.

12 NEWS RELEASE 06/12/09 "FASB Issues Statements 166 and 167 Pertaining to Securitizations and Special Purpose Entities", at: http://www.fasb.org/cs/ContentServer?pagename=FASB/FASBContent C/NewsPage\&cid= 1176156240834 . Last accessed 14 November 2016.

13 Available at: https://www.sec.gov/info/accountants/staffletters/hanish010808.pdf. Last accessed 14 November 2016.

14 NEWS RELEASE 06/12/09 “FASB Issues Statements 166 and 167 Pertaining to Securitizations and Special Purpose Entities", at: http://www.fasb.org/cs/ContentServer?pagename=FASB/FASBContent_C/NewsPage\&cid=1176156240834. Last accessed 14 November 2016. 
H3: The magnitude or significance of the association between ASR and audit fees are lower after the implementation of FAS No. 166 and FAS No. 167.

Prior to their introduction, the proposed changes attracted mixed comments. ${ }^{15}$ The accounting profession (e.g., AICPA, KPMG, EY, Deloitte, Grant Thornton LLP), standard setters (FRC) and regulators (e.g., FDIC, OCC, OTS) supported the proposed changes. From the banking industry, some supported the changes on the basis they would improve disclosure transparency and financial reporting (e.g., Goldman Sachs Group, Inc., Freddie Mac; Capital One; Citigroup) while others suggested that the proposed changes may result in overstatements of assets and liabilities of reporting entities that do not have real control of the assets or exposure to the economic risks of the liabilities (e.g., the Commercial Mortgage Securities Association, Mortgage Bankers Association, and the Real Estate Roundtable). These conflicting views raise some tension in $\mathrm{H} 3$ in that the negative responses by banking sector agencies suggest auditors may have to consider increased misstatement risks for reporting entities after the implementation of the new accounting standards.

15 The comment letters are available at: http://www.fasb.org/jsp/FASB/CommentLetter_C/CommentLetterPage\&cid=1218220137090\&project id=1620$\underline{100}$, http://www.fasb.org/jsp/FASB/CommentLetter_C/CommentLetterPage\&cid=1218220137090\&project_id=1610100 , and http://www.fasb.org/jsp/FASB/CommentLetter_C/CommentLetterPage\&cid=1218220137090\&project_id=FSP1 40R46R. Last accessed 14 November 2016. 


\section{RESEARCH DESIGN}

\section{Sample Selection and Data Sources}

Our sample of 553 listed BHCs from 2003 to 2013 yields 3,653 firm-year observations. We limit the sample to listed BHCs because audit fee information is publicly available for listed companies, and BHCs are the primary participants in asset securitization activities (Dechow et al. 2010; Barth et al. 2012). The sample period commences with 2003 because, although Y-9C Bank Regulatory reports start to disclose securitization activities in 2001, retained interests data became commonly available only from 2003.

We obtain annual financial data and asset securitization details from the FRB Y9-C Regulatory Filing database. The Y9-C reports are filed quarterly on BHCs with the total assets threshold of $\$ 150$ million before 2006 or $\$ 500$ million after $2006 .{ }^{16}$ Securitization information is disclosed in Schedule HC-S of Y9-C reports. Audit, restatement and internal control details are extracted from the Audit Analytics database. One-year standard deviations of daily stock returns are calculated from daily stock prices and dividends from the CRSP database. The intersection of the FRB Y-9C regulatory filing database and CRSP for listed BHCs yields 4,045 firm-year BHC observations. After matching with the Audit Analytics database we obtain 3,653 firm-year BHC observations, including 1,210 firm-years of non-securitizers and 2,443 firm-years of securitizers.

16 The increase in the reporting threshold after 2006 does not affect our results because most banks engaging in asset securitizations exceed the $\$ 500$ million asset threshold throughout our study period. 


\section{Audit Fee Model}

We use Equation (1) to test whether securitization risks are associated with audit fees. Equation (1) is an adaptation of the audit fee model for financial institutions in Fields et al. (2004).

$$
\begin{aligned}
\text { LNAF }= & \beta_{0}+\beta_{1} \text { ASR }+\beta_{2} \text { ASR } \times \text { LOSS }+\beta_{3} \text { LOSS }+\beta_{4} \text { LNTA }+\beta_{5} \text { BIGN }+ \\
& \beta_{6} \text { MARKET_VOLATILITY }+\beta_{7} \text { SAVING }+\beta_{8} \text { CAPRATIO }+\beta_{9} \text { TRANSACCT }+ \\
& \beta_{10} \text { SECURITIES }+\beta_{11} \text { COMMLOAN }+\beta_{12} \text { MTGLOAN }+\beta_{13} \text { INTANG }+\beta_{14} \text { CHGOFF }+ \\
& \beta_{15} \text { NONPERFORM }+\beta_{16} \text { INEFFICIENCY }+\beta_{17} \text { SENSITIVE }+\beta_{18} \text { INTDERIV }+ \\
& \beta_{19} \text { EXEMPT }+\sum \text { Year fixed effects }+\mu
\end{aligned}
$$

Variable definitions are summarized in Table 1. LNAF is the natural log of the audit fee. Following Cheng et al. (2011), the asset securitization risk factor (ASR) is the first factor generated from a principal factor analysis of total outstanding securitized assets, retained interests, non-performing securitized loans and charge-offs for securitized loans, each scaled by total assets, and the total securitization income scaled by total revenue on all securitizers. In our robustness tests, we also estimate the model using each of these variables in place of ASR. The individual risk variables and estimation of ASR are described further in the following subsection. We interact ASR with LOSS because we expect auditors' responses to securitization risks will have varied with differences in BHCs financial stress potential and earnings management. In our sample, the proportion of BHC's (firm-years) reporting a loss increased from 1.6 percent pre-GFC to 27.5 percent During-GFC and declined to 14.9 percent under FAS166/167.

\section{$<$ Insert Table 1 here $>$}

We include the control variables used in Fields et al. (2004) plus SENSITIVE, INTDERIV and EXEMPT. We include SENSITIVE as a measure of on-balance sheet interest rate risk, calculated as interest rate-sensitive assets minus interest rate-sensitive liabilities, divided by total 
assets, which we expect to be positively related to audit fees. INTDERIV proxies off-balance-sheet interest rate risks as the notional amount of a bank's interest rate derivatives divided by total assets. The potential effect of INTDERIV on audit fees is ambiguous because off-balance sheet interest rate derivatives can be used to hedge interest rate risks for on-balance sheet items or for risk-increasing speculative purposes; the complexity of derivatives may also increase audit fees. We include EXEMPT to control for the potential effect of a bank's exemption from reporting on internal controls under FDICIA Part 363 and SOX s.404 (Altamuro and Beatty 2010; Kanagaretnam, Krishnan, and Lobo 2010). ${ }^{17}$ We include this variable because prior research indicates that FDICIA has strengthened banks' business viability with increased ROA and ROE (Carnell 1997) and reduced failure risk (Benston and Kaufman 1998). Under SOX Section 404, the disclosure of ineffective internal control remediation improved earnings' properties (Ashbaugh-Skaife, Collins, Kinney and LaFond 2008). These findings suggest potential differences in risk characteristics and financial performance between exempt and non-exempt banks.

Hypothesis $\mathrm{H} 1$ is tested by estimating Equation (1) using the pooled BHC sample for the period 2003-3013. Hypotheses H2 and H3 are tested by estimating Equation (1) using the subsamples of Pre-GFC period (2003-2006), During-GFC period (2007-2009) and the FAS166/167 period (2010-2013).

The use of 2007 as the year the GFC commenced is consistent with prior studies. In an examination of the impact of corporate governance on the performance of financial firms, Erkens,

17 FDICIA Part 363 requires insured institutions with $\$ 1$ billion or more in total assets (\$500 million prior to 2005) to provide independently audited management reports on compliance and internal controls (FDIC 2005). Section 404 of SOX requires public companies to file certification of internal control effectiveness but exempts non-accelerators with market capitalization less than $\$ 75$ million. 
Hung, and Matos (2012) define the GFC as the period from January 2007 to September 2008. Balakrishnan, Watts, and Zuo (2016) define the period from August 2007 to August 2009 as the GFC period in examining the effect of accounting conservatism on firm value during the GFC, whereas Doogar et al. (2015) identify $2005-2007$ as the period leading to the GFC. In our sensitivity tests, we variously use 2006 as the cut-off year, or exclude 2006 and 2007 from the period tests.

The year 2010 is used as the start of the FAS166/167 period because those accounting standards took effect for the financial years commencing after November 2009, and 2009 is generally recognized as the last year of the GFC in the U.S. (NBER 2010). However, the potential audit impacts of FAS Nos. 166 and 167 are not clear. The regulatory changes were proposed in 2008 when the market and regulators observed problems in securitization accounting. Consequently, banks may have voluntarily adjusted accounting treatments of securitization transactions before 2010 (Gurun, Lerman, and Ronen 2012) or may have restructured arrangements to avoid consolidating off-balance sheet securitization vehicles under the proposed accounting standards (Bens and Monahan 2008). These possible behaviors reduce the likelihood of finding support for $\mathrm{H} 3$.

\section{Asset Securitization Risk Measures}

We test our hypotheses using a composite asset securitization risk factor generated from five individual asset securitization risk variables: SECINC, RETINT, ABS, NPL_SEC and CHOFF_SEC.

SECINC represents the gains on securitizations calculated as securitization income divided by total revenue; this is a risk proxy because research shows that manipulating gains on securitizations is used in managing earnings and capital adequacy (Degeorge et al. 1999; 
Matsumoto 2002; Dechow and Shakespeare 2009). Auditors should be sensitive to factors that might affect potential earnings manipulation and capital adequacy for banks.

RETINT is the level of explicit recourse, calculated as total retained interests (including retained interest only strips, retained credit enhancements and unused commitments to provide liquidity) divided by total assets (Barth et al. 2012). We expect auditors to consider retained interests when evaluating the inherent risks of asset securitizations because retained interests represent the explicit recourse support that banks provide for securitized assets. Retained interests are explicit contractual guarantees provided by banks that expose the bank to the risks of their securitized assets. Moreover, retained interests are designed to cover potential losses and represent a subordinate claim to the cash flows from the securitized assets with a higher risk of default than the sold tranches. In addition, auditors should consider retained interests when assessing risk because the valuation of retained interests is subjective and open to manipulation. The value of retained interests is based on the fair value estimate of the securitization components (FAS No. 140; FAS No. 157) but this involves subjective assumptions about default rates, prepayment rates and discount rates (FAS No. 157), thus increasing the sensitivity of the attributed value to the economic environment and management manipulation (Dechow et al. 2010). This measure may also reflect the credit quality of the underlying assets if originating banks retain the lower quality tranches.

The overall level of asset securitization activities (ABS) indicates the potential implicit recourse from a bank's securitized assets, and is calculated as total outstanding securitized assets divided by total assets (Barth et al. 2012). We include the level of securitized assets because credit risks embedded in asset securitizations are associated with the total securitized amount, the proportion of the retained interests, and the reported earnings in securitizations (Healy and 
Wahlen 1999). In addition, empirical evidence suggests banks' guarantees extend beyond retained interests to cover the total credit risk of the assets underlying the securities and the level of securitized assets affects the bank's exposure to implicit recourse (Higgins and Mason 2004; Calomiris and Mason 2004). ${ }^{18}$ Auditors should be sensitive to the risks associated with such implicit recourse.

Since the risks associated with securitizations largely depend on the quality of the underlying assets, we include the non-performing loan (NPL_SEC) and charge-off (CHOFF_SEC) ratios for securitized assets. If auditors consider the credit risks embedded in securitizations, the credit quality of the securitized assets, as reflected in the non-performing ratio and charge-off ratio of securitized assets, will influence audit effort and, therefore, will have a positive association with audit fees. NPL_SEC and CHOFF_SEC proxy for securitized asset quality and may reflect the relative importance of implicit or explicit recourse and the potential motivations of discretionary accounting. Consistent with Cheng et al. (2011), NPL_SEC is calculated as total non-performing securitized loans divided by total assets and CHOFF_SEC is calculated as total charge-offs for securitized loans divided by total assets.

Our primary measure of asset securitization risks (ASR) is a factor derived from principal factor analysis using the five asset securitization risk measures described above. This approach follows Cheng et al. (2011).

18 Banks often provide implicit recourse support for securitized assets. For example, Higgins and Mason (2004) report 17 recourse events involving 10 credit card banks from 1987 to 2001 and find that only two credit card securitizations that entered early amortization did not provide recourse support for the securitized assets. Banks voluntarily provided credit support by repurchasing assets or extending credit to the SPEs during the financial crisis of 2007-2009. In December 2007, Citigroup brought back onto its balance sheet $\$ 49$ billion of SPE assets that it had previously securitized. The same assets were valued at $\$ 87$ billion in August 2007 and Citicorp's total retained interests in all securitizations were only $\$ 25.8$ billion at December 31,2006 , indicating substantial losses to Citicorp in this striking example of honoring an implicit guarantee (Amiram, Landsman, Peasnell, and Shakespeare 2011). 
Descriptive statistics for these risk variables are presented in Panel A of Table 2 and their correlations are reported in Panel B. The factor weights of the ASR factor, obtained using principal factor analysis, are reported in Panel C of Table 2.

$<$ Insert Table 2 here $>$

\section{Descriptive Statistics}

The BHC data for estimating audit fees for the combined period 2003-2013 and the Pre-GFC, During-GFC and FAS166/167 sub-periods, and the significance tests for differences in means of the variables between the sub-periods, are reported in Table 3. Similar to prior bank studies (Fields et al. 2004; Karaoglu 2005; Chen et al. 2008; Ettredge et al. 2014b), the sample is highly skewed with respect to total assets. Mean audit fees increase in each sub-period. ${ }^{19}$ Mean securitized assets (ABS_AMT) increased significantly from $\$ 3.60$ billion pre-GFC to $\$ 7.32$ billion during-GFC, accompanied by a significant increase in mean audit fees (from $\$ 1.07$ million to $\$ 1.67$ million). Mean securitized assets then declined to $\$ 4.14$ billion with the implementation of FAS No. 166 and No. 167, but mean audit fees continued to increase. However, when securitized assets are scaled by total assets (ABS), the mean value almost halves from Pre-GFC (0.026) to During-GFC (0.014), with a small further decline in the FAS166/167 period (0.013), suggesting a declining trend in the use of asset securitization activities relative to asset growth in the banking industry. The dollar values of other asset securitization risk measures generally accord with the growth and decline of ABS_AMT. However, for the scaled risk measures, we

19 Ettredge et al. (2014a) and Krishnan and Zhang (2014) argue that managers exerted pressure on audit fees in the GFC and report that approximately 30 percent of audit engagements in 2008 faced fee-pressure. However, consistent with the descriptive statistics, we observe (but do not tabulate) positive year fixed effect tests for every year from 2004 to 2013, after controlling for BHC and auditor attributes. Our results are consistent with Hill et al. (1994), which show audit fees increased during the savings and loan crisis. 
observe a significant change in means only for securitization income (SECINC), the overall level of asset securitization activities (ABS) and for the factor variable ASR, which decreased from the Pre-GFC period to the During-GFC period.

$<$ Insert Table 3 here $>$

The proportion of BHCs audited by Big 4 auditors declines from 52 percent Pre-GFC to 44 percent During-GFC and 41 percent for the FAS166/167 period, consistent with the Ettredge et al. (2014b) observation of BHCs migrating from Big 4 to smaller auditors after the implementation of SOX s.404. Consistent with the general economic circumstances affecting the banking sector, asset quality deteriorated across the periods, as reflected in the non-performing loan ratio (NONPERFORM) and charge-off ratio (CHGOFF). Management efficiency (INEFFICIENCY) worsened after the onset of the GFC although INEFFICIENCY partially recovered after 2010, while the proportion of BHCs reporting losses increased from 1.6 percent in the Pre-GFC period to 27.5 percent in the during-GFC period, and then decreased to 14.9 percent for 2010-2013.

In our descriptive statistics and further tests, we distinguish securitizers from non-securitizers. Consistent with Cheng et al. (2011), we define a BHC as a securitizer if it reports at least one non-zero value in any of the five securitization risk variables comprising ASR during a given year. As shown in Table 3, the means for most variables are significantly different between securitizers and non-securitizers. Therefore, in our robustness tests, we also employ a Heckman two stage approach to address the potential bias in securitizers' self-selection.

Pearson correlations between the regression variables for the audit fee estimation are reported in Table 4. As expected, the presence of a Big 4 auditor is related to size (LNTA), and 
both are significantly related to LNAF. Unsurprisingly, the indicator variable LOSS is positively related to INEFFICIENCY. We also note that EXEMPT is more likely for smaller BHCs. For the continuous explanatory variables, there are no correlations greater than 0.46 . Overall, the correlation matrix does not suggest any substantial collinearity issues. VIF statistics also do not indicate multicollinearity concerns for the reported regressions.

$<$ Insert Table 4 here $>$

\section{REGRESSION RESULTS}

\section{Audit Fees and Asset Securitization Risks}

The main regression results on Hypotheses 1 to 3 are reported in Table 5 Panel A. For the full period and each sub-period, we report the models with and without the interaction term ASR $\times$ LOSS. For the Full Period regression, both without and with the interaction term, the coefficient for ASR is positive and significant ( $\mathrm{p} \leq 0.001$ ), supporting $\mathrm{H} 1$ that auditors respond to asset securitization risks, as reflected in audit fees.

\section{$<$ Insert Table 5 here $>$}

In the baseline models without the interaction term ASRxLOSS, the positive coefficient for ASR appears to increase with each period, but is not significant in the During-GFC period. However, these sub-period results may be distorted by audit risks associated with the increased incidence of BHCs reporting losses during the GFC. In our remaining discussion, and in our further tests, we use the full model (with the interaction term ASR $\times$ LOSS). 
In the Pre-GFC period, the positive impact of ASR on audit fees is much stronger for loss firms $\left(\beta_{1}+\beta_{2}=5.675, p=0.011\right)$ compared to non-loss firms $\left(\beta_{1}=0.665, p=0.002\right)$. These effects are economically significant. While there are various ways of assessing economic significance of the ASR, a reasonable (and generally accepted) guide is to look at the mean multiplier effect in the log-log model. For example, for the average securitizer BHC reporting a profit in the Pre-GFC period, the average effect of ASR on audit fees is a $0.80 \%$ increase in total audit fees, while for the average securitizer BHC reporting a loss in the Pre-GFC period, the average effect of ASR on audit fees is an $11.98 \%$ increase in total audit fees.

During the GFC, the impact of ASR is significantly positive for non-loss firms $\left(\beta_{1}=1.996\right.$, $\mathrm{p}=0.073$ ) but not for loss firms. This reduction in the impact of ASR from the Pre-GFC period to the During-GFC period for loss firms but not for non-loss firms provides qualified evidence in relation to $\mathrm{H} 2$.

In the FAS166/167 period, ASR is significantly positive for loss firms $\left(\beta_{1}+\beta_{2}=2.251, \mathrm{p}=\right.$ 0.006), but not for non-loss firms; this has some similarity to the Pre-GFC period, but the ASR effect is much weaker after the implementation of FAS166/167. These results provide qualified support for $\mathrm{H} 3$.

It is plausible that, in the During-GFC period, auditors focused on the BHC's financial risk (as signaled by losses) rather than asset securitization risks. An untabulated analysis indicates that, during the GFC, auditors remain sensitive to loss-making banks' exposure to major financial risks represented by the exposure to mortgage loans (MTGLOAN), nonperforming loans (NONPERFORM) and interest rate sensitivity (INTDERIV). We argue that this indicates that 
auditors remain sensitive to financial risks throughout the study period, but that misstatement risks associated with securitizations are less relevant to banks reporting losses. ${ }^{20}$

In the FAS166/167 period, when the GFC impact may have diminished, auditors are sensitive to ASR for loss-making BHCs. This is consistent with the proposition that auditors' exhibit concern for two types of risk associated with securitizations: financial risks and misstatement risks, but the importance of the two types of risk vary under the different regimes. Prior to the GFC, there were few BHCs reporting losses, and we cannot distinguish between the impacts of financial and misstatement risks on auditor effort. During the GFC, BHCs reporting losses are less likely to be using securitizations to manipulate their accounts but BHCs reporting profits may represent higher misstatement risks based on securitizations. Post GFC, although financial risks remain a concern, the new accounting standards (FAS Nos. 166 and 167) greatly reduce the prospects for BHCs to use securitizations to manipulate their accounts. Consequently, auditors' sensitivity to ASR for loss-making BHCs indicates their concern with the financial risks associated with securitizations.

To examine whether Big $\mathrm{N}$ and non-Big $\mathrm{N}$ auditors responded differently to asset securitization risks, we extend the analysis by re-estimating the audit fee model separately for the Big $\mathrm{N}$ and non-Big $\mathrm{N}$ subsamples. The results are reported in Table 5 Panel $\mathrm{B}$. The main results (with the ASR $\times$ LOSS interaction) hold for the Big $\mathrm{N}$ subsample. However, for the non-Big $\mathrm{N}$ subsample, the full period sample result holds but there are no significant ASR effects for audit fees in any of the sub-periods. This suggests that the Big $\mathrm{N}$ auditors were more responsive to

20 The suggestion that auditors are less concerned with misstatement risks for BHCs reporting losses is supported by the results for our 'securitization gains' test, reported later under Additional Analyses, in which LOSS is not significantly associated with reported securitization gains (Table 7 Panel D). 
securitization risks than non-Big $\mathrm{N}$ auditors, consistent with the proposition that the Big $\mathrm{N}$ audit firms provide higher quality audits in the banking sector.

These results suggest that, before the GFC, Big N auditors were generally more sensitive to the financial risks associated with asset securitizations, rather than accounting manipulations (as suggested by the lesser sensitivity to securitization risks for non-loss firms); but this emphasis changed with the onset of the GFC. During the GFC, Big N auditors exhibit significant sensitivity to ASR for non-loss firms but not for loss firms, and their effort in relation to loss firms appears to have increased in the GFC period, irrespective of ASR; the effect for ASR in LOSS firms is not significant. This suggests that auditors were not concerned with earnings manipulations associated with asset securitizations if firms reported losses, but had increased their general sensitivity to going-concern threats during the GFC. After the GFC and with the implementation of FAS Nos. 166 and 167, Big N auditors appear to have reverted to emphasizing financial risks associated with asset securitization (which are of greater concern for BHCs reporting losses) and were less concerned that securitizations were used to manage earnings. This is consistent with FAS Nos. 166 and 167 reducing opportunities for accounting manipulations based on asset securitizations. We further explore these potential changes in auditors' concerns with securitization risks in our robustness tests, when we test the effects of each of the component variables of ASR.

\section{ROBUSTNESS TESTS}

We conducted a variety of robustness tests of our main model, as described below. For efficiency, we do not tabulate these results. Our main results are robust to all of these tests. 
We tested the individual securitization risk measures (ABS, RETINT, NPL_SEC, CHOFF_SEC and SECINC) and their interactions with LOSS, in place of the ASR factor variable. The results are generally consistent with the ASR analysis; however, CHOFF_SEC is not significant in any of the periods, ABS is not significant in the During-GFC period and NPL_SECxLOSS is not significant in the FAS166/167 period.

To control for securitizers' self-selection bias, we re-estimated our main model using a two-stage Heckman using SENSITIVE as the instrumental variable in stage 1 and dropping it from the second-stage audit fee model (Equation 1). ${ }^{21}$ SENSITIVE is significant in the first stage but the Inverse Mills Ratio is not significant in the second stage, and other coefficients are consistent with the reported main test results, including the interaction of ASR and LOSS.

We partitioned our sample into large and small BHCs based on median total assets. Descriptively, larger BHC securitizers are more active in securitization activities, more likely to have a Big 4 auditor, less likely to report a loss, have large proportions of intangible assets, are more sensitive to interest rate risks, and have more off-balance sheet interest rate derivatives. The subsample results are consistent with the main results.

There is broad agreement that the GFC period was 2007-2009 (Erkens et al. 2012; Balakrishnan et al. 2016) but Doogar et al. (2015) argue that 2006 experienced some GFC impact and suggest the economic circumstances and associated government intervention may have increased the difficulties for auditors to identify and analyze risks in 2008-2009. It can also be argued that the biggest influences of the GFC were not reflected in the economy until 2008. In addition, auditor behavior in the FAS 166/167period of 2010-2013 may be affected by lingering

21 The first stage securitizer self-selection model is SECURITIZER $=\beta_{0}+\beta_{1}$ LNTA $+\beta_{2}$ BIGN $+\beta_{3}$ SECURITIES + $\beta_{4}$ MTGLOAN $+\beta_{5}$ SENSITIVE $+\sum$ Year fixed effects $+\mu$. Variables are defined in Table 1. 
GFC concerns. Therefore, we variously re-estimated our main model excluding either or both of 2006 and 2007, or excluding 2008 and 2009, observations. The results are consistent with our main findings.

FAS No. 157, issued in September 2006, established a measurement hierarchy for the fair value of assets, based on whether the prices of inputs were "observable" or "unobservable". Assets are classed as Level 3 assets when, in the absence of observable market prices, they are reported using firm-determined fair values. Internal models to estimate fair values are used frequently in asset securitization transactions when reliable market prices are not available for comparable inputs. Internally generated values may have higher inherent risk or are more difficult to verify, thus requiring more audit effort or more reliance on specialists. When we include the value of Level 3 assets (divided by total assets) for post-2006 observations, the variable is positively associated with audit fees but the main results for our variables of interest are not affected.

\section{ADDITIONAL ANALYSES}

In this section, we report additional analyses that: (1) examine the relevance of discretionary loan loss provisions for earnings management; (2) examine the impact of the additional audit effort associated with BHCs' securitization risks (AFSEC) on financial reporting quality by testing its impact on the probability of subsequent restatements and the extent to which the additional audit effort associated with asset securitizations constrained BHCs' use of gains from securitization; and (3) seek corroborating evidence of auditor behavior by examining going-concern audit opinions and subsequent BHC failure and financial distress. 


\section{Controlling for Management Discretionary Reporting}

Asset securitizations and audit fees should be related if asset securitizations are used for manipulating reported earnings and capital (Rosenblatt, Johnson, and Mountain 2005; Karaoglu 2005; Dechow and Shakespeare 2009). To examine this issue further, we include discretionary loan loss provisions (DLLP) in the audit fee models. Following Kanagaretnam et al. (2010), DLLP are the residuals obtained by estimating Equation (3).

$$
\begin{aligned}
\text { LLP }= & \alpha+\beta_{1} \text { LLAlag }+\beta_{2} \text { NPLlag }+\beta_{3} \Delta \text { NPL }+\beta_{4} L C O+\beta_{5} \Delta \text { LOAN }+ \\
& \beta_{6} \text { LOAN }+\Sigma \beta_{j} \text { LOANCATEGORY }+\sum \text { Year fixed effects }+\mu
\end{aligned}
$$

Variable definitions are in Table 1. We label the absolute value of DLLP as DLLP_ABS and include this as additional control variables in Equation (1), together with ASR $\times$ LOSS. As reported in Table 6, the coefficients for ASR and ASR $\times$ LOSS remain consistent with the main results, and audit fees have a positive association with DLLP_ABS.

We also divide the sample into the income-increasing DLLP and income-decreasing DLLP subsamples. For BHCs with an income-increasing DLLP, the main results hold after controlling for the discretionary loan loss provisions, and audit fees increase with the increase in the magnitude of income-increasing DLLP. ${ }^{22}$ For BHCs with income-decreasing DLLP, ASR and ASR $\times$ LOSS are not significantly associated with LNAF. Consistent with our previous analysis, we also estimate the results separately for the non-Big $\mathrm{N}$ and Big $\mathrm{N}$ subsamples. The full sample results generally hold for the Big N but not for the non-Big N. Consistent with our other Big N versus non-Big N comparisons, the ABS_DLLP results hold for the Big N but not for the non-Big

22 The negative sign for income increasing DLLP indicates audit fees increase with the magnitude of income-increasing DLLP. 
N. For the income-increasing DLLP subsample, the auditors' concerns with loss-making BHCs during the GFC applies only to the non-Big N while during the post-GFC or FAS166/167 period, the auditors' concerns with loss-making BHCs apply only to the Big N. However, splitting the sample by both DLLP type and auditor type produces very small samples that both reduce confidence in, and constrain further investigation of, these results.

$<$ Insert Table 6 Here $>$

\section{The Impact of Marginal Securitization Audit Effort on Accounting Manipulations}

To examine whether the marginal audit effort associated with asset securitization risks (AFSEC) is associated with audit quality, we test its impact on accounting manipulations as proxied by subsequent restatements and contemporaneous gains on securitizations (based on Dechow et al. 2010). We estimate AFSEC as the fitted value of audit fees (in dollars, scaled by total assets) attributable to ASR. To obtain AFSEC, we use a two-step regression approach. We first drop ASR from Equation (1), re-estimate the model and obtain the unexplained LNAF. We then regress the unexplained LNAF against ASR. From this second regression, we obtain AFSEC as the exponential of the predicted audit fee $\left(\exp \left(\beta_{1} \mathrm{ASR}\right)\right)$ for securitizers and scale it by total assets. $^{23}$

\section{AFSEC and Restatements}

If the marginal audit effort associated with BHC securitization risks improves BHC financial reporting quality, AFSEC should reduce the likelihood of subsequent restatements. To

23 We estimate AFSEC using this two-step regression approach because the exponential form of the audit fee model when unlogged impedes the calculation of marginal audit fee effects for individual variables. To gauge the economic relevance of the imputed audit effort, the marginal audit fee associated with ASR is scaled by total assets. 
test this proposition, we adapt the restatement models in Blankley, Hurtt, and MacGregor (2012) and Ettredge et al. (2014a) for BHCs and include AFSEC, as presented in Equation (4). Because our main results indicate that audit effort responses to securitization risks varied across the three sub-periods, we interact AFSEC with sub-period indicators for GFC and FAS166/167.

$$
\begin{aligned}
\text { RESTATEMENT }= & \beta_{0}+\beta_{1} \text { AFSEC }+\beta_{2} \text { AFSEC } \times \text { GFC }+\beta_{3} \text { AFSEC } \times \text { FAS166 } / 167+ \\
& \beta_{4} \text { GFC }+\beta_{5} \text { FAS } 166 / 167+\beta_{6} \text { LNTA }+\beta_{7} \text { COMMLOAN }+ \\
& \beta_{8} \text { INTANG }+\beta_{9} \text { INTDERIV }+\beta_{10} \text { CAPRATIO }+\beta_{11} \text { LLP }+\beta_{12} \text { M\&A }+ \\
& \beta_{13} \text { ICMW }+\beta_{14} \text { SPECIALITEM }+\beta_{15} \text { BIGN }+\sum \text { Year fixed effects }+\mu
\end{aligned}
$$

Variable definitions are in Table 1. Descriptive statistics for the additional variables in this model are reported in Table 7 Panel A, the restatements are described in Panel B, and the regression results are reported in Panel C.

$<$ Insert Table 7 Here $>$

We identify 316 subsequent restatements for financial statements issued during our study period, of which 177 are for irregularities (of which 129 are for securitizers) and 139 are for errors (of which 98 are for securitizers). In our data, irregularities are concentrated in the Pre-GFC period (62\% of irregularities) and errors are concentrated in the FAS166/167 period (55\% of errors). As shown in Panel A of Table 7, the restatement rate is slightly higher for securitizers (9.3\% for securitizers compared to $7.4 \%$ for non-securitizers).

For all restatements, irrespective of type, the logistic regression result for Equation (4) for the full sample of BHCs (Table 7 Panel C) yields a significant negative coefficient for AFSEC but this is limited to the Pre-GFC period. The net effects for AFSEC during the GFC $\left(\beta_{1}+\beta_{2}\right)$ or under FAS166/167 $\left(\beta_{1}+\beta_{3}\right)$ are not significantly different from zero. When we distinguish between restatements for irregularities and errors, as reported in Panel C, the results are more 
nuanced. Based on the full sample, audit effort attributed to securitization risks reduces the likelihood of restatements for irregularities Pre-GFC and During-GFC $\left(\beta_{1}+\beta_{2}=562.477\right.$, $\mathrm{p}=0.078$ ) but not for the FAS166/167 period. Audit effort attributed to securitization risks does not reduce the likelihood of restatements for errors Pre-GFC or During-GFC but does reduce it under FAS166/167 $\left(\beta_{1}+\beta_{3}=-653.841, p=0.057\right)$. These results may influenced by the variance distortion effects of the zero values on AFSEC for non-securitizers. When we estimate the regressions for the subsample of securitizers only (untabulated), AFSEC reduces the likelihood of restatements due to irregularities during the Pre-GFC period but has no significant impact thereafter. For the likelihood of restatements due to error, AFSEC is not significant pre-GFC but significantly negative both during the GFC $\left(\beta_{1}+\beta_{2}=-1691.392, p=0.023\right)$ and post-GFC under FAS166/167 $\left(\beta_{1}+\beta_{3}=-2068.505, p=0.008\right)$. These results seem to reflect the likely type of restatement for each period. For pre-GFC BHC reports, 80 percent of restatements were due to irregularities. During the GFC, the split is fairly even between irregularities and errors (54\% vs 46\%). Post-GFC, under FAS166/167, 68 percent of restatements were due to errors.

We replicate this analysis separately for Big $\mathrm{N}$ auditors and non-Big $\mathrm{N}$ auditors (untabulated). The results hold only for Big $\mathrm{N}$ auditors (consistent with our main ASR results), albeit with stronger significance levels) and there are no significant coefficients for AFSEC for non-Big $\mathrm{N}$ firms, which is consistent with the absence of a significant relation between LNAF and ASR for non-Big $\mathrm{N}$ in the sub-periods.

\section{AFSEC and Gains on Securitizations}

Based on the approach in Dechow et al. (2010), modified for BHCs, we estimate the association between AFSEC and the BHC's reported securitization gains for the subsample of securitizers: 


$$
\begin{aligned}
\text { SEC_GAIN }= & \beta_{0}+\beta_{1} \text { AFSEC }+\beta_{2} \text { AFSEC } \times \text { GFC }+\beta_{3} \text { AFSEC } \times F A S 166 / 167+\beta_{4} \text { GFC }+ \\
& \beta_{5} \text { FAS166 } / 167+\beta_{6} \text { MARKET_VOLATILITY }+\beta_{7} \text { PRE-SEC EARNINGS }+\mu
\end{aligned}
$$

Variable definitions are in Table 1. Descriptive statistics for the additional variables in this model are reported in Table 7 Panel A. The regression results, as reported in Table 7 Panel D, are consistent with the restatements test; AFSEC has a significant negative association with SEC_GAIN prior to the GFC but not thereafter. Consistent with our results for the main model and the restatement tests, we find the results hold for Big $\mathrm{N}$ audits but not for non-Big $\mathrm{N}$ audits. In the GFC period, we obtain an unexpected positive effect for non-Big N AFSEC. Overall, we conclude that the marginal audit effort associated with securitization risks by Big $\mathrm{N}$ auditors constrained the extent to which BHCs extracted gains from securitizations prior to the onset of the GFC, and suggest this was subsumed by other risks during the GFC and then rendered irrelevant through the application of FAS166/167.

\section{Going Concern Opinions and ASR}

Krishnan and Sengupta (2011) suggest that comparing the results of audit fee models and going-concern opinion (GCO) models may provide a complementary assessment on how auditors respond to particular risk factors. We test the association between ASR and GCO using two models: the GCO model in Gaganis, Pasiouras, and Spathis (2013), modified to include ASR; and

a model we adapted from Fields et al. (2004). ${ }^{24}$ We do not identify any significant association between GCOs and ASR. Following Chen, Lam, Smieliauskas, and Ye (2016), we also regressed

24 The model we adapted from Fields et al. (2004) is: GCO $=\alpha+\beta_{1} \mathrm{ASR}+\beta_{2} \mathrm{ASR} \times \mathrm{LOSS}+\beta_{3} \mathrm{LNTA}+\beta_{4} \mathrm{BIGN}+$ $\beta_{5}$ STDRET $+\beta_{6}$ SAVING $+\beta_{7}$ LOSS $+\beta_{8}$ CAPRATIO $+\beta_{9}$ TRANSACCT $+\beta_{10}$ SECURITIES + $\beta_{11}$ COMMLOAN $+\beta_{12}$ MTGLOAN $+\beta_{13}$ INTANG $+\beta_{14}$ CHGOFF $+\beta_{15}$ NONPERFORM $+\beta_{16}$ INEFFICIENCY $+\beta_{17}$ SENSITIVE $+\beta_{18}$ INTDERIV $+\beta_{19}$ EXEMPT $+\mu$. 
each of Type I and Type II errors as dependent variables, and find that ASR is not significantly associated with auditors' GCO errors.

\section{CONCLUDING DISCUSSION}

Using publicly available U.S. BHC data from 2003 to 2013, we analyze how asset securitization risks are related to bank audit fees in the lead-up to and during the GFC, and whether the relations changed following the introduction of FAS Nos. 166 and 167. We also examine whether the incremental auditor effort attributed to asset securitization risks is related to earnings restatements and securitization gains. The relatively stable regulatory and accounting environment during 2003 to 2009 is an excellent context to examine whether auditor behavior in response to asset securitization risks varied when the economic environment changed from prosperity to recession. The period 2010 to 2013 , after the implementation of FAS No. 166 and FAS No. 167, allows us to examine the effect of these new accounting standards that limit the discretionary use of accounting for asset securitization transactions and non-consolidation of asset securitization.

The GFC highlighted the material impact of asset securitization on the economy, financial markets and individual firms. Criticisms of auditors' efforts and capabilities in auditing asset securitizations arose after several audit failure cases related to asset securitizations in the banking industry. In response to the criticism of "where were the auditors in asset securitizations", our evidence that auditors did respond to asset securitization risks before the GFC, and that auditors

modified their risk focus during the GFC, partially counters criticisms of auditors around the financial crisis. 
We find that asset securitization risks have a significant positive association with audit fees for Big $\mathrm{N}$ auditors but not for non-Big $\mathrm{N}$ auditors, indicating Big $\mathrm{N}$ auditors were attentive to securitization risks both before and during the GFC. Big $\mathrm{N}$ auditors were sensitive to asset securitisation risks before the GFC but, during the GFC, it appears that financial distress become such a more pervasive risk concern for Big $\mathrm{N}$ auditors, such that securitisation risks did not have a significant additional impact on risk assessments for BHCs reporting a loss during the GFC.

We find that, prior to the GFC, the audit effort attributed to asset securitization risks by Big $\mathrm{N}$ auditors, but not by non-Big $\mathrm{N}$ auditors, reduced the likelihood of subsequent restatements and constrained reported gains on securitizations. Similarly, we find that, for Big N auditors, but not for non-Big $\mathrm{N}$ auditors, the audit effort attributed to asset securitisation risks reduced reported securitisation gains prior to the GFC, but not thereafter. While our results are consistent with the expected effects of FAS Nos. 166 and 167 in constraining the use of securitizations to manipulate earnings and balance sheet positions, we cannot fully distinguish this effect from the possible abatement of financial risk that was a consequence of the recovery from the GFC.

Our analysis does not reveal whether auditors responded to securitizations risks or the GFC by changing audit hours, engagement team composition or the billing rates charged to the clients in response to asset securitization risk. While we focus on the audit effort implications of asset securitizations, investors or regulators may look for more direct evidence concerning the contribution of audits to reporting quality and audit quality in relation to securitization activities; we leave this opportunity for future research. Nonetheless, our findings that audit fees reflect asset securitization risks for Big $\mathrm{N}$ auditors should be meaningful to the auditing profession and to financial market participants. 


\section{References}

Altamuro, J., and A. Beatty. 2010. How does internal control regulation affect financial reporting? Journal of Accounting and Economics 49 (1-2): 58-74.

Ambrose, B. W., M. LaCour-Little and A. B. Sanders. 2005. Does regulatory capital arbitrage, reputation, or asymmetric information drive securitization? Journal of Financial Services Research 28 (1): 113-133.

Amiram, D., W. R. Landsman, K. V. Peasnell, and C. Shakespeare. 2011. Market reaction to securitization retained interest impairments during the financial crisis of 2007-2008: Are implicit guarantees worth the paper they're not written on? Working paper. Available at SSRN: http://ssrn.com/abstract=1508664.

Ashbaugh-Skaife, H., D. Collins, W. Kinney, and R. LaFond. 2008. The effect of internal control deficiencies and their remediation on accrual quality. Accounting Review 83 (1): 217-250.

Balakrishnan, K., R. L. Watts, and L. Zuo. 2016. The effect of accounting conservatism on corporate investment during the Global Financial Crisis. Journal of Business Finance \& Accounting 43 (5-6): 513-542.

Barth, M. E., G. Clinch, and T. Shibano. 2003. Market effects of recognition and disclosure. Journal of Accounting Research 41 (4): 581-609.

Barth, M. E., G. Ormazabal, and D. J. Taylor. 2012. Asset securitizations and credit risk. The Accounting Review 87 (2): 423-448.

Basel Committee on Banking Supervision. 2008. External audit quality and banking supervision. Bank of International Settlements. ISBN 92-9131-783-7.

Beatty, A., and S. Liao. 2014. Financial accounting in the banking industry: A review of the empirical literature. Journal of Accounting and Economics 58 (2-3): 339-383.

Beaulieu, P. R. 2001. The effects of judgments of new clients' integrity upon risk judgments, audit evidence, and fees. Auditing: A Journal of Practice and Theory 20 (2): 85-99.

Bedard, J. C., and K. M. Johnstone. 2004. Earnings manipulation risk, corporate governance risk, and auditors' planning and pricing decisions. The Accounting Review 79 (2): 277-304.

Bens, D., and S. Monahan. 2008. Altering investment decisions to manage financial reporting outcomes: Asset-backed commercial paper conduits and FIN 46. Journal of Accounting Research 46 (5): 1017-1105.

Benston, G., G. Kaufman. 1998. Deposit insurance reform in the FDIC improvement act: The experience to date. Economic Perspectives 2: 2-20.

Blankley, A. I., Hurtt, D. N., and J. E. MacGregor. 2012. Abnormal Audit fees and restatements. Auditing: A Journal of Practice and Theory 31 (1): 79-96.

Boo, E., and D. Sharma. 2008. Effect of regulatory oversight on the association between internal governance characteristics and audit fees. Accounting and Finance 48: 51-71.

Calomiris, C. W., and J. R. Mason. 2004. Credit card securitization and regulatory arbitrage. Journal of Financial Services Research 26 (1): 5-27.

Carnell, S. 1997. Treasury defends FDICIA bank reform. Journal of Accountancy 183: 15.

Chen, F., Lam, K., Smieliauskas, W., and M. Ye. 2016. Auditor conservatism and banks' measurement uncertainty during the financial crisis. International Journal of Auditing 20: $52-65$.

Chen, W., C. Liu, and S. G. Ryan. 2008. Characteristics of securitizations that determine issuers' retention of the risks of the securitized assets. The Accounting Review 83 (5): 1181-1215. 
Cheng, M., and M. Neamtiu. 2009. An empirical analysis of changes in credit rating properties: Timeliness, accuracy and volatility. Journal of Accounting and Economics 47 (1-2): 108-130.

Cheng, M., D. Dhaliwal, and M. Neamtiu. 2011. Asset securitization, securitization recourse, and information uncertainty. The Accounting Review 86 (2): 541-568.

Dechow, P. M., and C. Shakespeare. 2009. Do managers time securitization transactions to obtain accounting benefits? The Accounting Review 84(1): 99-132.

Dechow, P. M., L. A. Myers, and C. Shakespeare. 2010. Fair value accounting and gains from asset securitizations: A convenient earnings management tool with compensation side-benefits. Journal of Accounting and Economics 49 (1-2): 2-25.

Degeorge, F., J. Patel, and R. Zeckhauser. 1999. Earnings management to exceed thresholds. Journal of Business 72 (1): 1-33.

Doogar, R., S. Rowe, and P. Sivadasan. 2015. Asleep at the wheel (again)? Bank audits during the lead-up to the financial crisis. Contemporary Accounting Research, 32 (1): 358-391.

Erkens, D. H., M. Hung, and P. Matos. 2012. Corporate governance in the 2007-2008 financial crisis: Evidence from financial institutions worldwide. Journal of Corporate Finance 18 (2): 389-411.

Ettredge, M., E. Emeigh. and C. Li. 2014a. Fee pressure and audit quality. Accounting, Organizations and Society 39: 247-263.

Ettredge, M., Y. Xu, and H. Yi. 2014b. Fair value measurements and audit fees: Evidence from the banking industry. Auditing: A Journal of Practice and Theory 33 (3): 33-58.

Federal Deposit Insurance Corporation (FDIC). 2005. Annual independent audits and reporting requirements amendments to Part 363. Financial Institution Letters FIL-119-2005. Available at: http://www.fdic.gov/news/news/financial/2005/ fil11905a.html.

Fields, L. P., D. R. Fraser, and M. S. Wilkins. 2004. An investigation of the pricing of audit services for financial institutions. Journal of Accounting and Public Policy 23 (1): 53-77.

Financial Accounting Standards Board. 2000. Accounting for Transfers and Servicing of Financial Assets and Extinguishments of Liabilities, a Replacement of FASB Statement No. 125. Statement of Financial Accounting Standards No. 140. Norwalk, CT: FASB.

Financial Accounting Standards Board. 2003. Consolidation of Variable Interest Entities. FASB Interpretation No. 46 (Revised December 2003). Norwalk, CT: FASB.

Financial Accounting Standards Board. 2006a. Accounting for Servicing of Financial Assets an Amendment of FASB Statement No. 140. Statement of Financial Accounting Standards No. 156. Norwalk, CT: FASB.

Financial Accounting Standards Board. 2006b. Fair Value Measurements. Statement of Financial Accounting Standards No. 157. Norwalk, CT: FASB.

Financial Accounting Standards Board. 2009a. Accounting for Transfers of Financial Assets an Amendment of FASB Statement No. 140. Statement of Financial Accounting Standards No. 166. Norwalk, CT: FASB.

Financial Accounting Standards Board. 2009b. Amendments to FASB Interpretation No. 46 (R). Statement of Financial Accounting Standards No. 167. Norwalk, CT: FASB.

Financial Accounting Standards Board. 2009c. FASB Issues Statements 166 and 167 Pertaining to Securitizations and Special Purpose Entities, News Release 06/12/09, Norwalk, CT, June $12,2009$.

Gaganis, C., F., Pasiouras, and C. Spathis. 2013. Regulations and audit opinions: Evidence from EU banking institutions. Computational Economics 41 (3): 387-405. 
Giannone, J. A. and Davies, M. 2008. Lazard CEO sees world's market woes just beginning. Reuters, November 30, 2008. Accessed November 14, 2016: http://www.reuters.com/article/us-financial-lazard-blackstone-idUSTRE49T77O20081030

Gul, F. A., C. Chen, and J. Tsui. 2003. Discretionary accounting accruals, managers' incentives, and audit fees, Contemporary Accounting Research 20 (3): 441-464.

Gurun, U. G., A. Lerman, and J. Ronen. 2012. Anticipatory and implementation effects of FIN 46 on the behavior of different market participants. Asia-Pacific Journal of Accounting \& Economics 19 (1): 1608-1625.

Hay, D., R. Knechel, and N. Wong. 2006. Audit fees: A meta-analysis of the effect of supply and demand attributes, Contemporary Accounting Research 23 (1): 141-191.

Healy, P. M., and J. Wahlen. 1999. A review of the earnings management literature and its implications for standard setting. Accounting Horizons 13 (4): 365-383.

Higgins, E., and J. R. Mason. 2004. What is the value of recourse to asset backed securities? A study of credit card bank ABS Rescues. Journal of Banking and Finance 28 (4): 857-874.

Hill, J., R. J. Ramsay, and R. T. Simon, 1994. Audit fees and client business risk during the S\&L crisis: Empirical evidence and directions for future research. Journal of Accounting and Public Policy 13 (3): 185-123.

Houston, R. W., M. F. Peters, and J. H. Pratt. 1999. The audit risk model, business risk and audit-planning decisions. The Accounting Review 74 (3): 281-298.

Kanagaretnam, K., G. Krishnan, and G. Lobo. 2010. An empirical analysis of auditor independence in the banking industry. The Accounting Review, 85 (6): 2011-2046.

Kane, G.D. 1997. The problem of how to account for asset securitization transactions. Journal of Accounting Education 15 (1): 39-51.

Karaoglu, E. 2005. Regulatory capital and earnings management in banks: The case of loan sales and securitizations. FDIC Center for Financial Research Working Paper No. 2005-05.

Knechel, W. R., G. V. Krishnan, M. Pevzner, L. Bhaskar, and U. Velury. 2013. Audit quality: Insight from the academic literature. Auditing: A Journal of Practice and Theory 32 (1): 385-421.

Krishnan, G. V., and P. Sengupta. 2011. How do auditors perceive recognized vs. disclosed lease and pension obligations? Evidence from fees and going-concern opinions. International Journal of Auditing 15: 127-149.

Krishnan, G. V., and Y. Zhang. 2014. Is there a relation between audit fee cuts during the global financial crisis and banks' financial reporting quality? Journal of Accounting and Public Policy 33: 279-300.

Landsman, W. R., K. V. Peasnell, and C. Shakespeare. 2008. Are asset securitizations sales or loans? The Accounting Review 83 (5): 1251-1272.

Lobo, G. J., and Y. Zhao. 2013. Relation between audit effort and financial report misstatements: Evidence from quarterly and annual restatements. The Accounting Review 88 (4): 1385-1412.

Lyon, J. D., and M. V. Maher. 2005. The importance of business risk in setting audit fees: Evidence from cases of client misconduct. Journal of Accounting Research 43 (1): 133-151.

Matsumoto, D. A. 2002. Management's incentives to avoid negative earnings surprises. The Accounting Review 77 (3): 483-514.

National Bureau of Economic Research (NBER). 2010. Business Cycle Dating Committee, National Bureau of Economic Research. http://www.nber.org/cycles/sept2010.html, last access 26 Oct 2015. 
Niu, F. F., and G. D. Richardson. 2006. Are securitizations in substance sales or secured borrowings? Capital-market evidence. Contemporary Accounting Research 23 (4): 1105-1133.

Office of Federal Housing Enterprise Oversight (OFHEO). 2006. Report of the Special Examination of Fannie Mae (May 2006).

Palepu, K. G., S. Srinivasan, and A. Sesia. (2009) New Century Financial Corporation. Harvard Business School Case 109-034, October 2009.

Pavel, C., and D. Phillis. 1987. Why commercial banks sell loans: An empirical analysis. Federal Reserve Bank of Chicago Economic Perspectives 11: 3-14.

Phillips, F. 1999. Auditor attention to and judgments of aggressive financial reporting. Journal of Accounting Research 37 (1): 167-189.

Rosenblatt, M., J. Johnson, and J. Mountain. 2005. Securitization Accounting, the Ins and Outs (and some Do's and Don'ts) of FASB 140, FIN 46R, IAS 39 and More. 7th edition, New York, NY: Deloitte.

Ryan, S. G. 2007. Financial Instruments and Institutions: Accounting and Disclosure Rules. Hoboken, NJ: John Wiley \& Sons.

Ryan, S. G. 2008. Accounting in and for the subprime crisis. The Accounting Review 83 (6): $1605-1638$

Schelleman, C., and W. R. Knechel. 2010. Short-term accruals and the pricing and production of audit services. Auditing: A Journal of Practice and Theory 29 (1): 221-250.

Schipper, K., and T. L. Yohn. 2007. Standard-setting issues and academic research related to the accounting for financial asset transfers. Accounting Horizons 21 (1): 59-80.

Schwarcz, S. L. 2004. Re-thinking the disclosure paradigm in a world of complexity. University of Illinois Law Review 1: 1-38.

Sikka, P. 2009. Financial crisis and the silence of the auditors. Accounting, Organizations and Society 34 (6-7): 868-873.

Simunic, D. A. and M. T. Stein. 1996. The impact of litigation risk on audit pricing: A review of the economics and the evidence. Auditing: A Journal of Practice and Theory 15 (Supplement): 119-134.

Solomon, D. 2012. The rise of a giant: Securitization and the Global Financial Crisis. American Business Law Journal 49 (4): 859-890.

Standard \& Poor's. 2001. Corporate Rating Criteria.

Standard \& Poor's. 2008. Corporate Rating Criteria.

Treacy, W. F. and M. Carey. 1998. Credit risk rating at large US banks. Federal Reserve Bulletin 84: 897-921.

Wiggins, R. Z., R. L. Bennett, and A. Metrick. 2014. The Lehman Brothers bankruptcy D: The role of Ernst \& Young. Yale Program on Financial Stability Case Study 2014-3D-V1. 


\section{Appendix 1: Accounting Treatments on Asset Securitizations \\ Panel A: Accounting treatments under FAS 140, FAS 156 and FAS 166}

Fair Values

Cash proceeds

$\$ \quad 1,000$

Servicing asset

Interest-only strip receivables

\begin{tabular}{|c|c|c|c|c|c|c|c|}
\hline \multicolumn{4}{|c|}{ FAS 140 before Revision } & \multicolumn{4}{|l|}{ FAS 156} \\
\hline \multicolumn{4}{|c|}{ Carrying amounts based on the relative fair values } & \multicolumn{4}{|c|}{ Carrying amounts based on the relative fair value } \\
\hline & $\begin{array}{r}\text { Fair } \\
\text { value }\end{array}$ & $\begin{array}{r}\text { Pct of total } \\
\text { fair value }\end{array}$ & $\begin{array}{r}\text { Allocated carrying } \\
\text { amount }\end{array}$ & & $\begin{array}{r}\text { Fair } \\
\text { value }\end{array}$ & $\begin{array}{r}\text { Pct of total } \\
\text { fair value }\end{array}$ & $\begin{array}{r}\text { Allocated carrying } \\
\text { amount }\end{array}$ \\
\hline Loans sold & 1000 & $91 \%$ & 910 & Loans sold & 1040 & 94.55 & 945.5 \\
\hline Servicing asset & 40 & 3.6 & 36 & & & & \\
\hline $\begin{array}{l}\text { Interest-only strip } \\
\text { receivables }\end{array}$ & 60 & 5.4 & 54 & $\begin{array}{l}\text { Interest-only strip } \\
\text { receivables }\end{array}$ & 60 & 5.45 & 54.5 \\
\hline Total & 1100 & 100 & 1000 & Total & 1100 & 100 & 1000 \\
\hline Gains on sale & & & & Gains on sale & & & \\
\hline Net proceeds & $\$$ & 1000 & & Net proceeds & $\$$ & 1040 & \\
\hline $\begin{array}{l}\text { Carrying amount of } \\
\text { loans sold }\end{array}$ & & 910 & & $\begin{array}{l}\text { Carrying amount of } \\
\text { loans sold }\end{array}$ & & 945.5 & \\
\hline Gains on sale & & 90 & & Gains on sale & & 94.5 & \\
\hline Journal entry: & & & & Journal entry: & & & \\
\hline Cash & 1000 & & & Cash & 1000 & & \\
\hline Loan sold & & 910 & & $\begin{array}{l}\text { Interest-only strip } \\
\text { receivables }\end{array}$ & 54.5 & & \\
\hline Gains on sale & & 90 & & Servicing asset & 40 & & \\
\hline & & & & Loans sold & & 1000 & \\
\hline Servicing asset & 36 & & & Gains on sale & & 94.5 & \\
\hline Interest-only strip & 54 & & & & & & \\
\hline Loans sold & & 90 & & $\begin{array}{l}\text { Interest-only strip } \\
\text { receivables }\end{array}$ & 5.5 & & \\
\hline Interest-only strip* & 6 & & & $\begin{array}{l}\text { Other } \\
\text { comprehensive } \\
\text { income }\end{array}$ & & 5.5 & \\
\hline
\end{tabular}

Equity

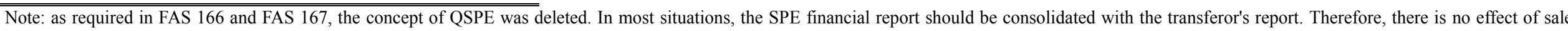

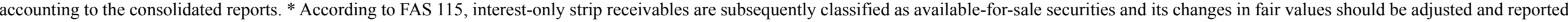
as other comprehensive income in the income statement. 


\section{Panel B: Comparison of Sale accounting and Borrowing Accounting}

(1) We assume that Bank A initially has loan assets of $\$ 4,000$, consisting of half of its total assets. As a bank meeting the capital requirements, Its owner's equity is $\$ 640,8 \%$ of total assets. Its ROI before the securitization is $10 \%$ (the example case is established based on the statistics from our 2006 BHC data).

\section{Initial Balance Sheet}

Other assets

Loans

$\$ 4,000$

$\$ 4,000$

Leverage (D/E ratio): 11.5

Liabilities

$\$ 7,360$

Total assets

$\$ 8,000$

Liabilities \& Equity

$\$ 8,000$

(2) Bank A securitizes $25 \%$ of the loans via a QSPE (Before FAS 156); the transaction is qualified as a sale according to FAS 140 .

The balance sheet after the securitization leverage: 10

\begin{tabular}{|c|c|c|c|}
\hline Cash & $\$ 1,000$ & Liabilities & $\$ 7,360$ \\
\hline Loans & $\$ 3,000$ & & \\
\hline Servicing asset & $\$ 36$ & & \\
\hline Interest-only strip & $\$ 60$ & & \\
\hline Other assets & $\$ 4,000$ & Equity & $\underline{\$ 736}$ \\
\hline Total assets & $\$ 8,096$ & Liabilities \& Equity & $\$ 8,096$ \\
\hline $\begin{array}{l}\text { The income statement after th } \\
\text { Net income other than } \\
\text { securitization } \\
\text { Gains on securitization }\end{array}$ & $\begin{array}{l}\$ 64 \\
\$ 90\end{array}$ & & \\
\hline Other comprehensive income & $\frac{\$ 6}{\$ 160}$ & & \\
\hline
\end{tabular}

(3) Bank A securitizes $25 \%$ of the loans via a QSPE (after FAS 156), qualifying a sale accounting according to FAS140 and FAS 156.

\begin{tabular}{|c|c|c|c|}
\hline \multicolumn{4}{|c|}{ The balance sheet after the securitization } \\
\hline Cash & $\$ 1,000$ & Liabilities & $\$ 7,360$ \\
\hline Loans & $\$ 3,000$ & & \\
\hline Servicing asset & $\$ 40$ & & \\
\hline Interest-only strip & $\$ 60$ & & \\
\hline Other assets & $\underline{\$ 4,000}$ & Equity & $\underline{\$ 740}$ \\
\hline Total assets & $\$ 8,100$ & Liabilities \& Equity & $\$ 8,100$ \\
\hline $\begin{array}{l}\text { The income statement a } \\
\text { Net income other than } \\
\text { securitization }\end{array}$ & ecuritizat & & \\
\hline $\begin{array}{l}\text { Gains on securitization } \\
\text { Other comprehensive } \\
\text { income }\end{array}$ & $\begin{array}{r}\$ 95 \\
\underline{\$ 6} \\
\$ 164\end{array}$ & & \\
\hline $\begin{array}{l}\text { (4) The transaction in (2 } \\
\text { The balance sheet after }\end{array}$ & $\begin{array}{l}\text { are recor } \\
\text { itization } 1\end{array}$ & $\begin{array}{l}\text { cured borrowing. } \\
3.06\end{array}$ & \\
\hline Cash & $\$ 1,000$ & Liabilities & $\$ 8,360$ \\
\hline Loans & $\$ 3,000$ & & \\
\hline $\begin{array}{l}\text { Securities pledged to } \\
\text { creditors }\end{array}$ & $\$ 1,000$ & Equity & $\underline{\$ 640}$ \\
\hline Other assets & $\$ 4,000$ & & \\
\hline Total assets & $\$ 9,000$ & Liabilities \& Equity & $\$ 9,000$ \\
\hline
\end{tabular}

There is no effect of a secured borrowing on the income statement. 
TABLE 1

Variable Definitions

\begin{tabular}{|c|c|c|}
\hline Variable & & Definition \\
\hline$\triangle \mathrm{LOAN}$ & $=$ & Changes in total loans outstanding divided by beginning total assets \\
\hline$\triangle \mathrm{NPL}$ & $=$ & Change in non-performing loans divided by total assets \\
\hline ABS & $=$ & Total outstanding securitized assets divided by total assets. \\
\hline ABS_AMT & $=$ & The balance of outstanding securitized assets, in thousand dollars. \\
\hline AFSEC & $=$ & $\begin{array}{l}\text { Additional audit fee on asset securitizations, estimated by regressing the residual from } \\
\text { Equation (1) (excluding ASR and SECURITIZER) against ASR and SECURITIZER, } \\
\text { and then take the exponential of the predicted audit fee from this second step model } \\
\text { and scaling it by total assets. }\end{array}$ \\
\hline ASR & $=$ & $\begin{array}{l}\text { The asset securitization risk factor, generated by a factor analysis based on ABS, } \\
\text { RETINT, NPL_SEC, CHOFF_SEC and SECINC. }\end{array}$ \\
\hline AUDIT_FEES & $=$ & Annual audit fee in dollars. \\
\hline $\mathrm{BIGN}-$ & $=$ & 1 if the incumbent auditor is a Big 4 auditor in the current year, 0 otherwise. \\
\hline CAPRATIO & $=$ & Risk-adjusted capital ratio: total regulatory capital divided by risk-weighted assets. \\
\hline CHGOFF & $=$ & Net charge-offs / allowance for loan and lease losses. \\
\hline CHGOFFscaled & $=$ & Net loan charge-offs (CHGOFF) divided by beginning total assets \\
\hline CHOFF_SEC & $=$ & Total charge-offs for securitized loans divided by total assets. \\
\hline CHOFF_SEC_AMT & $=$ & Total charge-offs for securitized loans, in thousand dollars. \\
\hline COMML̄OAN & $=$ & $\begin{array}{l}\text { Commercial loans / gross loans. Commercial loans involve commercial and industrial } \\
\text { loans, loans to depository institutions, acceptances issued by other banks, and } \\
\text { agricultural loans. }\end{array}$ \\
\hline DLLP & $=$ & $\begin{array}{l}\text { The discretionary loan loss provision, measured as the residual from the LLP } \\
\text { estimation model (Equation (5)) }\end{array}$ \\
\hline DLLP_ABS & $=$ & $\begin{array}{l}\text { Absolute value of discretionary loan loss provision, measured as the residual from the } \\
\text { LLP estimation model (Equation (5)) (DLLP). }\end{array}$ \\
\hline EBP & $=$ & Earnings before extraordinary items and LLP, divided by beginning total assets \\
\hline EXEMPT & $=$ & $\begin{array}{l}1 \text { if } \mathrm{BHC} \text { is exempted from FDICIA and SOX requirements for attestation of } \\
\text { management reports on compliance and internal control effectiveness, } 0 \text { otherwise. }\end{array}$ \\
\hline FAS166/167 & $=$ & 1 if the year is subject to FAS166/167, 2010-2013, and 0 otherwise. \\
\hline GFC & $=$ & 1 if the year is during the GFC, 2007-2009, and 0 otherwise. \\
\hline ICMW & $=$ & $\begin{array}{l}1 \text { if internal control material weaknesses are reported on the BHC during the year, and } \\
0 \text { otherwise. }\end{array}$ \\
\hline INEFFICIENCY & $=$ & $\begin{array}{l}\text { Management efficiency ratio: total operating expense (including interest expense) } \\
\text { divided by total revenue (including interest revenue). }\end{array}$ \\
\hline INTANG & $=$ & Intangible assets/total assets. \\
\hline INTDERIV & $=$ & Notional value of interest rate derivatives divided by total assets. \\
\hline LCO & $=$ & Net loan charge-offs divided by total assets \\
\hline LLAlag & $=$ & Beginning loan loss allowance divided by beginning total assets \\
\hline LLP & $=$ & Provision for loan losses, divided by total assets. \\
\hline LLPlag & $=$ & Provision for loan losses divided by beginning total assets \\
\hline LNAF & $=$ & Natural logarithm of annual audit fee, in dollars. \\
\hline LNMV & $=$ & The natural logarithm of market value at the end of the year \\
\hline LNTA & $=$ & Natural logarithm of total assets in dollars. \\
\hline LOAN & $=$ & Total loans outstanding divided by beginning total assets \\
\hline LOANCATEGORY & $=$ & $\begin{array}{l}\text { The vector of commercial loans, consumer loans, real estate loans, agriculture loans, } \\
\text { loans to foreign banks and governments, and loans to other depository institutions, } \\
\text { measured as the dollar value of each type of loan divided by beginning total assets. }\end{array}$ \\
\hline LOSS & $=$ & 1 if the $\mathrm{BHC}$ reports a loss, 0 otherwise. \\
\hline M\&A & $=$ & 1 if the $\mathrm{BHC}$ entered into merger or acquisition during the year, and 0 otherwise. \\
\hline MARKET_VOLATILITY & $=$ & Market volatility, measured as one-year standard deviation of daily stock returns. \\
\hline
\end{tabular}




\begin{tabular}{|c|c|}
\hline MTB & Market to book value ratio at the end of the year \\
\hline MTGLOAN & Mortgage loans divided by gross loans. \\
\hline NONPERFORM & $\begin{aligned}= & \text { Non-performing loans divided by gross loans. Non-performing loans are defined as } \\
& \text { loans } \geq 90 \text { day past due, non-accrual loans, leases and other assets. }\end{aligned}$ \\
\hline NPLlag & Beginning non-performing loans divided by beginning total assets \\
\hline NPLSEC & Total non-performing securitized loans / total assets. \\
\hline NPLSEC_AMT & Total nonperforming securitized loans, in thousand dollars. \\
\hline PRE-SEC EARNINGS & Earnings before securitization gain (SEC_GAIN) scaled by prior year equity. \\
\hline PSTLLPlag & Prior year's loan loss provision divided by beginning total assets \\
\hline RESTATE_ERROR & $\begin{array}{l}1 \text { if the BHC's financial statements are subsequently restated due to errors, and } 0 \\
\text { otherwise. }\end{array}$ \\
\hline RESTATE_IRREG & $\begin{array}{l}1 \text { if the BHC's financial statements are subsequently restated due to irregularities, and } \\
0 \text { otherwise. }\end{array}$ \\
\hline RESTATE_SEC & $\begin{array}{l}1 \text { if the BHC's financial statements are subsequently restated due to issues related to } \\
\text { asset securitizations, and } 0 \text { otherwise. }\end{array}$ \\
\hline RESTATEMENT & 1 if the BHC's financial statements are subsequently restated, and 0 otherwise. \\
\hline RETINT & $\begin{array}{l}\text { Total retained interests (including retained interest only strips, credit enhancements, } \\
\text { and commitments to provide liquidity) divided by total assets. }\end{array}$ \\
\hline RETINT_AMT & $\begin{array}{l}\text { The balance of total retained interests (including retained interest only strips, retained } \\
\text { credit enhancements, and unused commitments to provide liquidity), in thousand } \\
\text { dollars. }\end{array}$ \\
\hline SAVING & 1 if the $\mathrm{BHC}$ is a savings institution, 0 otherwise. \\
\hline SEC_GAIN & $\begin{array}{l}\text { Scaled securitization gains, calculated as net securitization income (SECINC_AMT) } \\
\text { divided by beginning total equity. }\end{array}$ \\
\hline SECINC & Net securitization income divided by total revenue. \\
\hline SECINC_AMT & Net securitization income, in thousands of dollars. \\
\hline SECURITITIES & Investment security assets divided by total assets. \\
\hline SECURITIZER & $\begin{array}{l}1 \text { when the BHC reports at least one non-zero value for any of the five securitization } \\
\text { risk factors, (securitized assets, retained interests, securitization incomes, } \\
\text { non-performing ratio, charge-off ratio for securitized assets), and } 0 \text { otherwise. }\end{array}$ \\
\hline SENSITIVE & $\begin{array}{l}\text { On-balance-sheet interest rate risk measure: (interest rate-sensitive assets - interest } \\
\text { rate-sensitive liabilities) divided by total assets. }\end{array}$ \\
\hline SPECIALITEM & Special item, scaled by total assets. \\
\hline TA & Total assets in thousand dollars. \\
\hline TCAPlag & Beginning total risk adjusted capital ratio \\
\hline TIER1lag & Beginning Tier 1 risk adjusted capital ratio \\
\hline TRANSACCT & $\begin{array}{l}\text { Transaction accounts (no-interest demand, interest-bearing checking, automatic } \\
\text { transfer from savings, and money market deposit accounts) / total deposits. }\end{array}$ \\
\hline
\end{tabular}


TABLE 2

Asset Securitization Risk Measures

Panel A: Distributional characteristics of the asset securitization risk variables

\begin{tabular}{lcccc}
\hline Variable & Mean & Std. Dev. & Min & Max \\
\hline ABS & 0.028 & 0.206 & 0 & 7.678 \\
RETINT & 0.001 & 0.006 & 0 & 0.096 \\
NPL_SEC & 0.002 & 0.011 & 0 & 0.257 \\
CHOFF_SEC & 0.0002 & 0.003 & 0 & 0.074 \\
SECINC_REV & 0.008 & 0.028 & -0.043 & 0.558 \\
ASR & 0.009 & 0.050 & -0.014 & 1.619 \\
\hline
\end{tabular}

Panel B: Pearson correlations of the asset securitization risk variable

\begin{tabular}{|c|c|c|c|c|c|c|}
\hline Variable & ABS & RETINT & NPL_SEC & CHOFF_SEC & SECINC & ASR \\
\hline $\mathrm{ABS}$ & 1 & & & & & \\
\hline RETINT & 0.249 & 1 & & & & \\
\hline NPL_SEC & 0.712 & 0.321 & 1 & & & \\
\hline CHOFF_SEC & 0.258 & 0.436 & 0.334 & 1 & & \\
\hline SECINC_REV & 0.418 & 0.363 & 0.527 & 0.710 & 1 & \\
\hline ASR & 0.981 & 0.315 & 0.774 & 0.386 & 0.582 & 1 \\
\hline
\end{tabular}

Panel C: Variable factor loadings in the asset securitization risk factor

\begin{tabular}{cccccccc}
\hline & & & & & & \multicolumn{3}{c}{$\begin{array}{c}\text { Squared } \\
\text { Multiple } \\
\text { Factor }\end{array}$} & ABS & RETINT & NPL_SEC & CHOFF_SEC & SECINC & Correlations & Eigen value \\
\hline ASR & 0.649 & 0.478 & 0.739 & 0.682 & 0.786 & $83.4 \%$ & 2.279 \\
\hline Variables are
\end{tabular}

Variables are defined in Table $1 ; \mathrm{n}=2,443$. All correlations in Panel $\mathrm{B}$ are significant at $\mathrm{p}<0.001$. 
TABLE 3

Descriptive Statistics

\begin{tabular}{|c|c|c|c|c|c|c|c|c|c|c|c|c|c|}
\hline \multirow{3}{*}{ Variable } & \multicolumn{7}{|c|}{ During-GF } & & & \multirow{3}{*}{$\begin{array}{c}\begin{array}{c}\text { Non- } \\
\text { Securitizer } \\
(\mathrm{n}=1,210)\end{array} \\
\text { Mean }\end{array}$} & \multirow{3}{*}{$\begin{array}{c}\begin{array}{c}\text { Securitizer } \\
(\mathrm{n}=2,443)\end{array} \\
\text { Mean }\end{array}$} & \multirow{2}{*}{\multicolumn{2}{|c|}{$\begin{array}{c}\text { Difference in Means } \\
\text { Securitizer vs. } \\
\text { Non-Securitizer }\end{array}$}} \\
\hline & \multicolumn{2}{|c|}{$\begin{array}{c}\text { Pooled BHCs } \\
(2003-2013) \\
(n=3,653)\end{array}$} & \multirow{2}{*}{$\begin{array}{c}\text { Pre-GFC } \\
(2003-2006)( \\
(\mathrm{n}=1,560)\end{array}$} & \multirow{2}{*}{$\left.\begin{array}{c}\mathrm{C} \\
(2007-2009) \\
(\mathrm{n}=864\end{array}\right)$} & \multirow{2}{*}{$\begin{array}{c}\text { FAS166/167 } \\
(2010-2013) \\
(\mathrm{n}=1,229) \\
\text { Mean }\end{array}$} & \multicolumn{2}{|c|}{$\begin{array}{c}\text { Difference in Means } \\
\text { Pre-GFC vs. } \\
\text { During-GFC }\end{array}$} & \multicolumn{2}{|c|}{$\begin{array}{c}\text { Difference in Means } \\
\text { During-GFC vs. } \\
\text { FAS166/167 }\end{array}$} & & & & \\
\hline & Mean & Median & & & & t-stat & $\mathrm{p}$-value & t-stat & $\mathrm{p}$-value & & & t-stat & p-value \\
\hline AUDIT_FEES (\$) & $1,604,419$ & 302,000 & $1,071,581$ & $1,669,092$ & $2,235,298$ & -2.300 & 0.022 & -1.610 & 0.107 & 655,549 & $2,074,388$ & -7.690 & $<0.001$ \\
\hline $\mathrm{LNAF}^{-}$ & 12.834 & 12.618 & 12.557 & 13.021 & 13.055 & -8.800 & $<0.001$ & -0.630 & 0.532 & 12.311 & 13.094 & -19.190 & $<0.001$ \\
\hline ABS_AMT $(\$, 000)$ & $4,662,197$ & 0 & $3,596,544$ & $7,323,129$ & $4,144,195$ & -1.690 & 0.091 & 1.360 & 0.173 & 0 & $6,971,350$ & -6.780 & $<0.001$ \\
\hline RET_INT_AMT $(\$, 000)$ & 108604 & 0 & 77733 & 249470 & 48,760 & -1.390 & 0.164 & 1.630 & 0.104 & 0 & 162395 & -3.590 & $<0.001$ \\
\hline NPL_SEC_AMT $(\$, 000)$ & 546,540 & 0 & 172,614 & 939,477 & 744,935 & -2.080 & 0.038 & 0.450 & 0.653 & 0 & 817,238 & -4.640 & $<0.001$ \\
\hline CHOFF_SEC_AMT $(\$, 000)$ & 84,911 & 0 & 36730 & 141,709 & 106138 & -1.890 & 0.059 & 0.550 & 0.584 & 0 & 126,966 & -4.740 & $<0.001$ \\
\hline SECINC_AMT $(\$, 000)$ & 72,721 & 30 & 84,322 & 99,063 & 39475 & -0.460 & 0.649 & 2.020 & 0.044 & 0 & 108,739 & -6.840 & $<0.001$ \\
\hline ABS & 0.019 & 0.000 & 0.026 & 0.014 & 0.013 & 1.860 & 0.064 & 0.310 & 0.755 & 0.000 & 0.028 & -6.770 & $<0.001$ \\
\hline RETINT & 0.000 & 0.000 & 0.001 & 0.001 & 0.000 & 0.370 & 0.711 & 1.400 & 0.162 & 0.000 & 0.001 & -6.340 & $<0.001$ \\
\hline NPL_SEC & 0.001 & 0.000 & 0.001 & 0.001 & 0.001 & -0.050 & 0.959 & -0.130 & 0.899 & 0.000 & 0.002 & -7.250 & $<0.001$ \\
\hline CHOFF_SEC & 0.000 & 0.000 & 0.000 & 0.000 & 0.000 & 0.220 & 0.825 & 1.230 & 0.219 & 0.000 & 0.000 & -4.750 & $<0.001$ \\
\hline SECINC & 0.005 & 0.000 & 0.006 & 0.004 & 0.004 & 2.170 & 0.030 & -0.150 & 0.879 & 0.000 & 0.008 & -14.150 & $<0.001$ \\
\hline ASR & 0.006 & 0.000 & 0.008 & 0.005 & 0.004 & 1.980 & 0.048 & 0.240 & 0.807 & 0.000 & 0.009 & -8.900 & $<0.001$ \\
\hline TA $(\$, 000)$ & $32,820,014$ & $1,807,161$ & $21,246,450$ & $37,190,078$ & $44,438,424$ & -2.020 & 0.044 & -0.730 & 0.465 & $6,120,652$ & $46,044,013$ & -8.390 & $<0.001$ \\
\hline LNTA & 21.694 & 21.315 & 21.436 & 21.867 & 21.899 & -6.380 & $<0.001$ & -0.450 & 0.652 & 21.035 & 22.020 & -20.120 & $<0.001$ \\
\hline BIGN & 0.465 & 0 & 0.522 & 0.435 & 0.413 & 4.140 & $<0.001$ & 0.990 & 0.320 & 0.274 & 0.560 & -17.590 & $<0.001$ \\
\hline STDRET & 0.326 & 0.067 & 0.340 & 0.290 & 0.334 & 3.140 & 0.002 & -1.160 & 0.245 & 0.424 & 0.277 & 6.540 & $<0.001$ \\
\hline SAVING & 0.067 & 0 & 0.062 & 0.039 & 0.094 & 2.470 & 0.014 & -5.170 & $<0.001$ & 0.046 & 0.078 & -3.880 & $<0.001$ \\
\hline LOSS & 0.122 & 0 & 0.016 & 0.275 & 0.149 & -16.700 & $<0.001$ & 6.920 & $<0.001$ & 0.132 & 0.117 & 1.290 & 0.196 \\
\hline CAPRATIO & 14.360 & 13.550 & 13.759 & 13.289 & 15.877 & 2.090 & 0.037 & -11.130 & $<0.001$ & 14.344 & 14.369 & -0.160 & 0.875 \\
\hline TRANSACCT & 0.607 & 0.609 & 0.583 & 0.547 & 0.679 & 5.670 & $<0.001$ & -19.730 & $<0.001$ & 0.588 & 0.616 & -4.750 & $<0.001$ \\
\hline SECURITIES & 0.208 & 0.189 & 0.219 & 0.179 & 0.214 & 8.550 & $<0.001$ & -7.500 & $<0.001$ & 0.213 & 0.205 & 1.850 & 0.064 \\
\hline COMMLOAN & 0.166 & 0.147 & 0.167 & 0.167 & 0.163 & 0.010 & 0.989 & 0.920 & 0.357 & 0.160 & 0.169 & -2.300 & 0.022 \\
\hline MTGLOAN & 0.303 & 0.300 & 0.304 & 0.283 & 0.318 & 3.380 & 0.001 & -5.610 & $<0.001$ & 0.276 & 0.317 & -8.190 & $<0.001$ \\
\hline INTANG & 0.017 & 0.010 & 0.017 & 0.020 & 0.015 & -2.900 & 0.004 & 4.950 & $<0.001$ & 0.011 & 0.020 & -14.310 & $<0.001$ \\
\hline CHGOFF & 0.409 & 0.288 & 0.236 & 0.515 & 0.553 & -16.830 & $<0.001$ & -1.640 & 0.102 & 0.376 & 0.425 & -3.100 & 0.002 \\
\hline NONPERFORM & 0.020 & 0.011 & 0.007 & 0.027 & 0.030 & -18.220 & $<0.001$ & -2.070 & 0.039 & 0.019 & 0.020 & -1.600 & 0.109 \\
\hline INEFFICIENCY & 0.770 & 0.750 & 0.738 & 0.833 & 0.767 & -12.570 & $<0.001$ & 7.690 & $<0.001$ & 0.783 & 0.764 & 3.400 & 0.001 \\
\hline SENSITIVE & 0.094 & 0.092 & 0.106 & 0.059 & 0.102 & 5.390 & $<0.001$ & -5.290 & $<0.001$ & 0.085 & 0.098 & -1.800 & 0.072 \\
\hline INTDERIV & 0.387 & 0.005 & 0.254 & 0.320 & 0.603 & -0.630 & 0.530 & -1.870 & 0.062 & 0.027 & 0.565 & -6.920 & $<0.001$ \\
\hline EXEMPT & 0.207 & 0 & 0.221 & 0.188 & 0.202 & 1.990 & 0.047 & -0.810 & 0.415 & 0.322 & 0.149 & 11.330 & $<0.001$ \\
\hline $\begin{array}{l}\text { Proportion of cases that } \\
\text { are securitizers }\end{array}$ & 0.669 & 1 & 0.657 & 0.675 & 0.679 & -0.890 & 0.375 & -0.220 & 0.823 & 0.000 & 1.000 & - & - \\
\hline
\end{tabular}


TABLE 4

Pearson Correlations (Sample Period: 2003-2013)

\begin{tabular}{|c|c|c|c|c|c|c|c|c|c|c|c|c|c|c|c|c|c|c|}
\hline Variables & 1 & 2 & 3 & 4 & 5 & 6 & 7 & 8 & 9 & 10 & 11 & 12 & 13 & 14 & 15 & 16 & 17 & 18 \\
\hline 1. LNAF & 1 & & & & & & & & & & & & & & & & & \\
\hline 2. LNTA & $0.921^{\mathrm{c}}$ & 1 & & & & & & & & & & & & & & & & \\
\hline 3. BIGN & $0.596^{\mathrm{c}}$ & $0.553^{\mathrm{c}}$ & 1 & & & & & & & & & & & & & & & \\
\hline 4. STDRET & $-0.238^{\mathrm{c}}$ & $-0.266^{\mathrm{c}}$ & $-0.183^{\mathrm{c}}$ & 1 & & & & & & & & & & & & & & \\
\hline 5. SAVING & $-0.096^{\mathrm{c}}$ & $-0.102^{\mathrm{c}}$ & $-0.075^{\mathrm{c}}$ & $0.058^{\mathrm{c}}$ & 1 & & & & & & & & & & & & & \\
\hline 6. LOSS & $0.030^{\mathrm{a}}$ & $-0.030^{\mathrm{a}}$ & $-0.103^{c}$ & $0.046^{\mathrm{c}}$ & -0.017 & 1 & & & & & & & & & & & & \\
\hline 7. CAPRATIO & $0.083^{\mathrm{c}}$ & 0.013 & $0.042^{\mathrm{b}}$ & -0.010 & $0.062^{\mathrm{c}}$ & $-0.107^{\mathrm{c}}$ & 1 & & & & & & & & & & & \\
\hline 8. TRANSACCT & $0.166^{\mathrm{c}}$ & $0.182^{\mathrm{c}}$ & $0.168^{c}$ & $-0.111^{\mathrm{c}}$ & -0.008 & $-0.192^{\mathrm{c}}$ & $0.146^{\mathrm{c}}$ & 1 & & & & & & & & & & \\
\hline 9. SECURITIES & -0.010 & 0.014 & $0.134^{\mathrm{c}}$ & -0.009 & $-0.059^{c}$ & $-0.146^{\mathrm{c}}$ & $0.288^{\mathrm{c}}$ & $0.128^{\mathrm{c}}$ & 1 & & & & & & & & & \\
\hline 10. COMMLOAN & $0.220^{\mathrm{c}}$ & $0.214^{\mathrm{c}}$ & $0.239^{c}$ & $-0.107^{\mathrm{c}}$ & $-0.106^{\mathrm{c}}$ & $-0.085^{\mathrm{c}}$ & $-0.044^{\mathrm{c}}$ & $0.277^{\mathrm{c}}$ & -0.008 & 1 & & & & & & & & \\
\hline 11. MTGLOAN & $-0.098^{\mathrm{c}}$ & $-0.035^{\mathrm{b}}$ & $-0.047^{\mathrm{c}}$ & $0.053^{\mathrm{c}}$ & $0.200^{\mathrm{c}}$ & $-0.036^{\mathrm{b}}$ & 0.003 & $-0.031^{b}$ & $0.084^{\mathrm{c}}$ & $-0.458^{\mathrm{c}}$ & 1 & & & & & & & \\
\hline 12. INTANG & $0.414^{\mathrm{c}}$ & $0.407^{\mathrm{c}}$ & $0.284^{\mathrm{c}}$ & $-0.153^{\mathrm{c}}$ & 0.002 & $-0.109^{c}$ & $0.292^{\mathrm{c}}$ & $0.173^{\mathrm{c}}$ & $-0.034^{b}$ & $0.064^{\mathrm{c}}$ & -0.004 & 1 & & & & & & \\
\hline 13. CHGOFF & $0.187^{\mathrm{c}}$ & $0.140^{\mathrm{c}}$ & -0.010 & 0.016 & $-0.047^{\mathrm{c}}$ & $0.423^{\mathrm{c}}$ & $0.156^{\mathrm{c}}$ & -0.038 & $-0.090^{c}$ & 0.006 & $-0.051^{\mathrm{c}}$ & $0.093 \mathrm{c}$ & 1 & & & & & \\
\hline 14. NONPERFORM & $40.133^{\mathrm{c}}$ & $0.065^{\mathrm{c}}$ & $-0.083^{\mathrm{c}}$ & $0.178^{\mathrm{c}}$ & -0.026 & $0.517^{\mathrm{c}}$ & -0.016 & $-0.145^{\mathrm{c}}$ & $-0.094 \mathrm{c}$ & $-0.094^{c}$ & -0.015 & $-0.095^{\mathrm{c}}$ & $0.410^{\mathrm{c}}$ & 1 & & & & \\
\hline 15. INEFFICIENCY & $-0.083^{\mathrm{c}}$ & $-0.163^{\mathrm{c}}$ & $-0.180^{\mathrm{c}}$ & $0.191^{\mathrm{c}}$ & $0.027^{\mathrm{a}}$ & $0.561^{\mathrm{c}}$ & $-0.125^{\mathrm{c}}$ & $-0.228^{\mathrm{c}}$ & $-0.077^{\mathrm{c}}$ & $-0.116^{\mathrm{c}}$ & $0.037^{\mathrm{b}}$ & $-0.146^{\mathrm{c}}$ & $0.241^{\mathrm{c}}$ & $0.332^{\mathrm{c}}$ & 1 & & & \\
\hline 16. SENSITIVE & $0.260^{\mathrm{c}}$ & $0.265^{\mathrm{c}}$ & $0.205^{\mathrm{c}}$ & $-0.091^{\mathrm{c}}$ & $-0.055^{\mathrm{c}}$ & $-0.080^{\mathrm{a}}$ & $0.044^{\mathrm{c}}$ & $0.282 \mathrm{c}$ & $-0.124^{\mathrm{c}}$ & $0.233^{\mathrm{c}}$ & $-0.185 \mathrm{c}$ & $0.093^{\mathrm{c}}$ & -0.016 & $-0.083^{\mathrm{c}}$ & $-0.137^{\mathrm{c}}$ & 1 & & \\
\hline 17. INTDERIV & $0.403^{\mathrm{c}}$ & $0.412^{\mathrm{c}}$ & $0.125^{\mathrm{c}}$ & $-0.036^{\mathrm{b}}$ & -0.027 & -0.024 & 0.016 & 0.021 & $-0.100^{c}$ & $0.063^{\mathrm{c}}$ & -0.017 & $0.063^{\mathrm{c}}$ & $0.056^{\mathrm{c}}$ & $0.032^{\mathrm{a}}$ & -0.002 & $0.087^{\mathrm{c}}$ & 1 & \\
\hline 18. EXEMPT & $-0.466^{\mathrm{c}}$ & $-0.496^{\mathrm{c}}$ & $-0.345^{\mathrm{c}}$ & $0.307^{\mathrm{c}}$ & $0.149^{c}$ & $0.041^{\mathrm{b}}$ & 0.006 & $-0.157^{\mathrm{c}}$ & $-0.043^{\mathrm{c}}$ & $-0.159^{c}$ & $0.059^{\mathrm{c}}$ & $-0.232^{\mathrm{c}}$ & $-0.053^{\mathrm{c}}$ & $0.028^{\mathrm{a}}$ & $0.163^{\mathrm{c}}$ & $-0.127^{\mathrm{c}}$ & $-0.061^{\mathrm{c}}$ & 1 \\
\hline 19. ABS & $0.161^{\mathrm{c}}$ & $0.164^{\mathrm{c}}$ & $0.066^{\mathrm{c}}$ & -0.027 & 0.033 & 0.011 & $0.038^{\mathrm{b}}$ & -0.013 & $-0.046^{\mathrm{b}}$ & $-0.038^{b}$ & $0.135^{\mathrm{c}}$ & $0.137^{\mathrm{c}}$ & $0.051^{\mathrm{b}}$ & $0.056^{\mathrm{c}}$ & -0.010 & $0.048^{\mathrm{c}}$ & $0.081^{\mathrm{c}}$ & -0.023 \\
\hline 20. RETINT & $0.193^{\mathrm{c}}$ & $0.189^{\mathrm{c}}$ & $0.111^{\mathrm{c}}$ & $-0.034^{\mathrm{c}}$ & -0.016 & 0.020 & $0.069^{\mathrm{c}}$ & $-0.063^{\mathrm{c}}$ & -0.006 & $-0.032^{\mathrm{a}}$ & -0.018 & $0.100^{\mathrm{c}}$ & $0.075^{\mathrm{c}}$ & $0.100^{\mathrm{c}}$ & $-0.051^{\mathrm{c}}$ & $0.031^{\mathrm{a}}$ & $0.083^{\mathrm{c}}$ & $-0.053^{\mathrm{c}}$ \\
\hline 21.NPL_SEC & $0.269^{\mathrm{c}}$ & $0.268^{\mathrm{c}}$ & $0.113^{\mathrm{c}}$ & -0.033 & $0.053^{\mathrm{a}}$ & $0.047^{\mathrm{c}}$ & 0.025 & -0.017 & $-0.071^{\mathrm{c}}$ & $-0.028^{\mathrm{a}}$ & $0.157^{\mathrm{c}}$ & $0.136^{\mathrm{c}}$ & $0.074^{\mathrm{c}}$ & $0.143^{\mathrm{c}}$ & 0.011 & $0.062^{\mathrm{c}}$ & $0.230^{\mathrm{c}}$ & $-0.053^{b}$ \\
\hline 22. CHOFF_SEC & $0.179^{c}$ & $0.184^{\mathrm{c}}$ & $0.084^{\mathrm{c}}$ & $-0.028^{\mathrm{a}}$ & -0.021 & 0.006 & $0.081^{\mathrm{c}}$ & $-0.031^{\mathrm{a}}$ & $-0.049^{\mathrm{c}}$ & -0.010 & $-0.030^{\mathrm{a}}$ & $0.114^{\mathrm{c}}$ & $0.091^{\mathrm{c}}$ & $0.028^{\mathrm{a}}$ & $-0.034^{b}$ & $0.037^{\mathrm{b}}$ & $0.162^{\mathrm{c}}$ & $-0.040^{\mathrm{b}}$ \\
\hline 23. SECINC & $0.246^{\mathrm{c}}$ & $0.247^{\mathrm{c}}$ & $0.124^{\mathrm{c}}$ & $-0.035^{\mathrm{b}}$ & 0.026 & -0.016 & $0.032^{\mathrm{a}}$ & $-0.031^{\mathrm{a}}$ & $-0.065^{\mathrm{c}}$ & -0.005 & $0.050^{\mathrm{c}}$ & $0.150^{\mathrm{c}}$ & $0.077^{\mathrm{c}}$ & $0.031^{\mathrm{a}}$ & $-0.049^{b}$ & $0.043^{\mathrm{c}}$ & $0.138^{\mathrm{c}}$ & $-0.046^{\mathrm{C}}$ \\
\hline 24. ASR & $0.203^{\mathrm{c}}$ & $0.205^{\mathrm{c}}$ & $0.088^{\mathrm{c}}$ & $-0.032^{\mathrm{a}}$ & $0.036^{\mathrm{b}}$ & 0.010 & 0.041 & -0.019 & $-0.056^{\mathrm{c}}$ & $-0.034^{b}$ & $0.133^{\mathrm{c}}$ & $0.155^{\mathrm{c}}$ & $0.064^{\mathrm{c}}$ & $0.064^{\mathrm{c}}$ & -0.018 & $0.053^{\mathrm{c}}$ & $0.112^{\mathrm{c}}$ & $-0.032^{\mathrm{a}}$ \\
\hline
\end{tabular}


TABLE 5

Audit Fees and Asset Securitization Risks Regressions

Panel A: Combined sample results

\begin{tabular}{|c|c|c|c|c|c|c|c|c|c|c|c|c|c|c|c|c|}
\hline \multirow[b]{3}{*}{ Variable } & \multicolumn{4}{|c|}{$\begin{array}{c}\text { Full Period } \\
(2003-2013)\end{array}$} & \multicolumn{4}{|c|}{$\begin{array}{c}\text { Pre-GFC } \\
(2003-2006)\end{array}$} & \multicolumn{4}{|c|}{$\begin{array}{l}\text { During-GFC } \\
(2007-2009)\end{array}$} & \multicolumn{4}{|c|}{$\begin{array}{l}\text { FAS166/167 } \\
(2010-2013)\end{array}$} \\
\hline & \multicolumn{2}{|c|}{ No interaction } & \multicolumn{2}{|c|}{ With interaction } & \multicolumn{2}{|c|}{ No interaction } & \multicolumn{2}{|c|}{ With interaction } & \multicolumn{2}{|c|}{ No interaction } & \multicolumn{2}{|c|}{ With interaction } & \multicolumn{2}{|c|}{ No interaction } & \multicolumn{2}{|c|}{ With interaction } \\
\hline & Coeff & $\mathrm{p}$-value & Coeff & $\mathrm{p}$-value & Coeff & $\mathrm{p}$-value & Coeff & $\mathrm{p}$-value & Coeff & $\mathrm{p}$-value & Coeff & $\mathrm{p}$-value & Coeff & $\mathrm{p}$-value & Coeff & p-value \\
\hline ASR & 0.793 & 0.001 & 0.743 & $<0.001$ & 0.699 & 0.001 & 0.665 & 0.002 & 0.758 & 0.325 & 1.996 & 0.073 & 1.200 & 0.047 & 0.103 & 0.901 \\
\hline ASRxLOSS & - & - & 0.725 & 0.562 & - & - & 5.010 & 0.024 & - & - & -2.111 & 0.124 & - & - & 2.148 & 0.053 \\
\hline LOSS & 0.006 & 0.886 & 0.00005 & -0.079 & -0.118 & 0.268 & -0.160 & 0.140 & 0.095 & 0.031 & 0.111 & 0.014 & 0.002 & 0.967 & -0.012 & 0.782 \\
\hline LNTA & 0.613 & $<0.001$ & 0.613 & $<0.001$ & 0.598 & $<0.001$ & 0.598 & $<0.001$ & 0.597 & $<0.001$ & 0.594 & $<0.001$ & 0.620 & $<0.001$ & 0.623 & $<0.001$ \\
\hline BIGN & 0.446 & $<0.001$ & 0.445 & $<0.001$ & 0.459 & $<0.001$ & 0.458 & $<0.001$ & 0.405 & $<0.001$ & 0.409 & $<0.001$ & 0.416 & $<0.001$ & 0.412 & $<0.001$ \\
\hline MARKET_VOLATILITY & -0.009 & 0.477 & -0.009 & 0.482 & -0.183 & $<0.001$ & -0.183 & $<0.001$ & -0.014 & 0.812 & -0.017 & 0.767 & -0.003 & 0.780 & -0.003 & 0.765 \\
\hline SAVING $^{-}$ & 0.032 & 0.486 & 0.034 & 0.472 & -0.007 & 0.893 & -0.004 & 0.936 & 0.042 & 0.552 & 0.043 & 0.535 & 0.049 & 0.206 & 0.050 & 0.198 \\
\hline CAPRATIO & 0.018 & $<0.001$ & 0.017 & $<0.001$ & 0.009 & 0.002 & 0.009 & 0.002 & 0.014 & $<0.001$ & 0.014 & $<0.001$ & 0.027 & $<0.001$ & 0.027 & $<0.001$ \\
\hline TRANSACCT & -0.042 & 0.707 & -0.042 & 0.710 & 0.297 & $<0.001$ & 0.296 & $<0.001$ & -0.109 & 0.355 & -0.110 & 0.347 & -0.330 & $<0.001$ & -0.315 & $<0.001$ \\
\hline SECURITIES & -0.295 & 0.059 & -0.292 & 0.062 & -0.397 & $<0.001$ & -0.400 & $<0.001$ & 0.225 & 0.126 & 0.228 & 0.121 & -0.450 & $<0.001$ & -0.451 & $<0.001$ \\
\hline COMMLOAN & -0.033 & 0.930 & -0.032 & 0.915 & -0.033 & 0.805 & -0.029 & 0.828 & -0.003 & 0.985 & -0.001 & 0.997 & -0.262 & 0.044 & -0.274 & 0.035 \\
\hline MTGLOAN & -0.548 & $<0.001$ & -0.553 & $<0.001$ & -0.419 & $<0.001$ & -0.423 & $<0.001$ & -0.627 & $<0.001$ & -0.623 & $<0.001$ & -0.791 & $<0.001$ & -0.793 & $<0.001$ \\
\hline INTANG & 1.355 & 0.103 & 1.351 & 0.099 & 1.967 & 0.002 & 1.993 & 0.002 & 0.520 & 0.490 & 0.406 & 0.592 & 2.141 & 0.004 & 2.079 & 0.005 \\
\hline CHGOFF & 0.038 & 0.112 & 0.039 & 0.100 & 0.161 & 0.003 & 0.175 & 0.002 & 0.056 & 0.145 & 0.050 & 0.188 & -0.009 & 0.670 & -0.007 & 0.736 \\
\hline NONPERFORM & 3.067 & $<0.001$ & 3.035 & $<0.001$ & 6.538 & $<0.001$ & 5.890 & $<0.001$ & 2.279 & $<0.001$ & 2.251 & $<0.001$ & 2.836 & $<0.001$ & 2.838 & $<0.001$ \\
\hline INEFFICIENCY & 0.476 & $<0.001$ & 0.478 & $<0.001$ & 1.219 & $<0.001$ & 1.219 & $<0.001$ & 0.131 & 0.098 & 0.125 & 0.115 & 0.556 & $<0.001$ & 0.560 & $<0.001$ \\
\hline SENSITIVE & 0.031 & 0.505 & 0.031 & 0.545 & -0.018 & 0.716 & -0.018 & 0.714 & 0.095 & 0.311 & 0.099 & 0.288 & 0.159 & 0.017 & 0.161 & 0.015 \\
\hline INTDERIV & 0.021 & $<0.001$ & 0.021 & $<0.001$ & 0.021 & $<0.001$ & 0.021 & $<0.001$ & 0.027 & $<0.001$ & 0.025 & $<0.001$ & 0.017 & $<0.001$ & 0.017 & $<0.001$ \\
\hline EXEMPT & -0.079 & 0.040 & -0.078 & 0.040 & -0.028 & 0.476 & -0.026 & 0.506 & -0.026 & 0.588 & -0.028 & 0.556 & -0.095 & 0.003 & -0.091 & 0.004 \\
\hline Constant & -1.551 & 0.001 & -1.135 & 0.018 & -1.543 & $<0.001$ & -1.524 & $<0.001$ & -0.443 & 0.217 & -0.380 & 0.292 & -1.062 & $<0.001$ & -1.146 & $<0.001$ \\
\hline$\overline{\text { F-value }}$ & 280.82 & $<0.001$ & 278.01 & $<0.001$ & 606.64 & $<0.001$ & 576.50 & & 407.48 & $<0.001$ & 386.78 & & 782.19 & & 742.90 & \\
\hline Adj. $\mathrm{R}^{2}$ & 0.897 & & 0.898 & & 0.881 & & 0.882 & & 0.895 & & 0.895 & & 0.920 & & 0.920 & \\
\hline $\mathrm{n}$ & 3653 & & 3653 & & 1560 & & 1560 & & 864 & & 864 & & 1229 & & 1229 & \\
\hline Maximum VIF & 2.872 & & 2.872 & & 3.170 & & 3.170 & & 3.365 & & 3.365 & & 3.408 & & 3.408 & \\
\hline
\end{tabular}


Table 5 continued

Panel B: Non-Big N versus Big N results

\begin{tabular}{|c|c|c|c|c|c|c|c|c|c|c|c|c|c|c|c|c|}
\hline \multirow[b]{3}{*}{ Variable } & \multicolumn{4}{|c|}{$\begin{array}{l}\text { Full Period } \\
(2003-2013)\end{array}$} & \multicolumn{4}{|c|}{$\begin{array}{c}\text { Pre-GFC } \\
(2003-2006)\end{array}$} & \multicolumn{4}{|c|}{$\begin{array}{l}\text { During-GFC } \\
(2007-2009)\end{array}$} & \multicolumn{4}{|c|}{$\begin{array}{l}\text { FAS166/167 } \\
(2010-2013)\end{array}$} \\
\hline & \multicolumn{2}{|c|}{ No interaction } & \multicolumn{2}{|c|}{ With interaction } & \multicolumn{2}{|c|}{ No interaction } & \multicolumn{2}{|c|}{ With interaction } & \multicolumn{2}{|c|}{ No interaction } & \multicolumn{2}{|c|}{ With interaction } & \multicolumn{2}{|c|}{ No interaction } & \multicolumn{2}{|c|}{ With interaction } \\
\hline & Coeff & p-value & Coeff & p-value & Coeff & p-value & Coeff & p-value & Coeff & p-value & Coeff & p-value & Coeff & p-value & Coeff & $\mathrm{p}$-value \\
\hline \multicolumn{17}{|l|}{ Non-Big $N$} \\
\hline ASR & 0.291 & 0.008 & 0.295 & 0.007 & 0.210 & 0.471 & 0.200 & 0.493 & -3.278 & 0.294 & -5.040 & 0.191 & 0.500 & 0.708 & 0.833 & 0.571 \\
\hline ASRxLOSS & & & -0.553 & 0.817 & & & 97.808 & 0.131 & & & 5.029 & 0.433 & & & -1.839 & 0.588 \\
\hline LOSS & -0.002 & 0.965 & -0.001 & 0.979 & -0.308 & 0.029 & -0.342 & 0.017 & 0.025 & 0.645 & 0.017 & 0.747 & 0.075 & 0.095 & 0.078 & 0.085 \\
\hline Adj. $\mathrm{R}^{2}$ & 0.722 & & 0.723 & & 0.653 & & 0.655 & & 0.683 & & 0.683 & & 0.721 & & 0.721 & \\
\hline $\mathrm{n}$ & 1,954 & & 1,954 & & 745 & & 745 & & 488 & & 488 & & 721 & & 721 & \\
\hline \multicolumn{17}{|l|}{$\operatorname{Big} N$} \\
\hline ASR & 0.901 & 0.026 & 0.806 & 0.019 & 1.156 & 0.001 & 1.096 & 0.001 & 0.804 & 0.357 & 2.837 & 0.027 & 1.156 & 0.145 & -0.585 & 0.596 \\
\hline ASRxLOSS & & & 0.725 & 0.567 & & & 4.519 & 0.055 & & & -3.384 & 0.031 & & & 3.146 & 0.025 \\
\hline LOSS & 0.043 & 0.515 & 0.030 & 0.668 & 0.172 & 0.301 & 0.089 & 0.605 & 0.178 & 0.014 & 0.233 & 0.002 & -0.105 & 0.188 & -0.155 & 0.060 \\
\hline Adj. $\mathrm{R}^{2}$ & 0.887 & & 0.887 & & 0.876 & & 0.877 & & 0.879 & & 0.880 & & 0.906 & & 0.907 & \\
\hline $\mathrm{n}$ & 1,699 & & 1,699 & & 815 & & 815 & & 376 & & 376 & & 508 & & 508 & \\
\hline
\end{tabular}

Robust standard errors are clustered on BHCs for the full period regressions. All models control for year fixed effects. All p-values are two-tailed. Variables are defined in Table 1. 
TABLE 6

Audit Fees and Asset Securitization Risk Relations When Controlling for Discretionary Use of Loan Loss Provisions

\begin{tabular}{|c|c|c|c|c|c|c|c|c|c|c|c|c|}
\hline \multirow[b]{2}{*}{ Variable } & \multicolumn{4}{|c|}{ Full sample } & \multicolumn{4}{|c|}{ Non-Big N sample } & \multicolumn{4}{|c|}{ Big N sample } \\
\hline & $\begin{array}{c}\text { Full Period } \\
(2003-13)\end{array}$ & $\begin{array}{l}\text { Pre-GFC } \\
(2003-06)\end{array}$ & $\begin{array}{c}\text { During-GFC } \\
(2007-09)\end{array}$ & $\begin{array}{c}\text { FAS166/167 } \\
(2010-13)\end{array}$ & $\begin{array}{c}\text { Full Period } \\
(2003-13)\end{array}$ & $\begin{array}{l}\text { Pre-GFC } \\
(2003-06)\end{array}$ & $\begin{array}{c}\text { During-GFC } \\
(2007-09)\end{array}$ & $\begin{array}{c}\text { FAS166/167 } \\
(2010-13)\end{array}$ & $\begin{array}{c}\text { Full Period } \\
(2003-13)\end{array}$ & $\begin{array}{l}\text { Pre-GFC } \\
(2003-06)\end{array}$ & $\begin{array}{c}\text { During-GFC } \\
(2007-09)\end{array}$ & $\begin{array}{c}\text { FAS166/167 } \\
(2010-13)\end{array}$ \\
\hline \multicolumn{13}{|c|}{ Panel A: Absolute DLLP (ABS_DLLP) } \\
\hline ASR & $0.728 * * *$ & $0.662 * * *$ & $2.060 *$ & -0.221 & $0.276^{* *}$ & 0.205 & -4.860 & -1.020 & $0.791 * *$ & $1.004 * * *$ & $2.804 * *$ & -0.579 \\
\hline ASR $\times$ LOSS & 0.792 & $4.800 * *$ & -2.219 & $2.706^{* *}$ & -0.534 & 57.666 & 5.001 & 0.104 & 0.906 & $4.795 * *$ & $-3.215 * *$ & $3.439 * *$ \\
\hline DLLP_ABS & $9.767 * *$ & 1.825 & $16.985 * * *$ & 3.346 & 6.176 & -10.227 & 6.785 & $11.957 * *$ & $17.993 * *$ & $37.873^{* *}$ & $24.463 * * *$ & -0.011 \\
\hline $\operatorname{LOSS}^{-}$ & -0.012 & -0.129 & $0.097^{* *}$ & -0.018 & -0.000 & $-0.299 *$ & 0.033 & 0.058 & -0.017 & 0.098 & $0.168 * *$ & $-0.160 *$ \\
\hline F-value & 266.93 & 488.62 & 337.70 & 600.67 & 67.03 & 61.25 & 51.62 & 83.74 & 197.96 & 259.62 & 134.21 & 219.04 \\
\hline $\operatorname{Adj} \mathrm{R}^{2}$ & 0.897 & 0.880 & 0.897 & 0.920 & 0.719 & 0.646 & 0.690 & 0.721 & 0.887 & 0.876 & 0.882 & 0.906 \\
\hline $\mathrm{N}$ & 3,590 & 1,531 & 854 & 1,205 & 1911 & 727 & 479 & 705 & 1679 & 804 & 375 & 500 \\
\hline \multicolumn{13}{|c|}{ Panel B: Results for income-increasing DLLP subsample } \\
\hline ASR & $0.682 * * *$ & $0.603 * * *$ & 0.274 & -0.187 & $0.388 * * *$ & $\quad 0.277$ & -4.565 & -0.639 & $1.101 * * *$ & $1.247 * * *$ & 1.740 & -0.355 \\
\hline ASR $\times$ LOSS & $1.857 * * *$ & 105.497 & $21.492 * *$ & $2.780 * *$ & 2.379 & -1851.452 & $29.425 * * *$ & -0.587 & $1.983 * *$ & -169.705 & -13.943 & $4.370 * * *$ \\
\hline DLLP (signed) & $-19.357 * * *$ & -21.292 & -17.342 & -8.071 & $-22.446 * * *$ & -16.627 & $-26.305^{* *}$ & $-17.986 * *$ & -19.382 & $-55.764 * *$ & -11.980 & 0.381 \\
\hline LOSS & -0.042 & -0.238 & -0.015 & -0.012 & -0.013 & $-0.466^{* *}$ & -0.068 & 0.079 & -0.053 & 0.186 & 0.176 & -0.167 \\
\hline F-value & 217.78 & 282.59 & 177.54 & 318.63 & 58.78 & 34.73 & 42.29 & 50.76 & 128.38 & 137.14 & 66.04 & 96.93 \\
\hline $\operatorname{Adj} \mathrm{R}^{2}$ & 0.899 & 0.895 & 0.883 & 0.925 & 0.745 & 0.690 & 0.735 & 0.754 & 0.878 & 0.876 & 0.872 & 0.901 \\
\hline $\mathrm{N}$ & 1,870 & 762 & 515 & 593 & 1008 & 335 & 314 & 359 & 862 & 427 & 201 & 234 \\
\hline \multicolumn{13}{|c|}{ Panel C: Results for income decreasing DLLP subsample } \\
\hline ASR & 0.623 & 0.956 & 2.061 & 1.215 & $-5.433 *$ & -8.544 & -7.627 & -3.720 & 0.307 & 1.032 & 1.750 & 2.834 \\
\hline ASR $\times$ LOSS & 0.089 & 1.039 & -2.457 & 20.379 & -4.228 & 37.835 & 0.078 & -21.306 & 0.666 & 3.875 & -2.014 & 28.140 \\
\hline DLLP (signed) & 4.832 & $-16.139 *$ & 12.405 & 5.775 & -2.927 & $-20.613^{*}$ & -14.695 & $12.600^{*}$ & $17.899 * *$ & 29.865 & $25.704 * *$ & 6.197 \\
\hline LOSS & 0.026 & 0.116 & 0.128 & -0.040 & 0.059 & -0.068 & 0.129 & 0.060 & -0.033 & 0.083 & 0.120 & -0.170 \\
\hline F-value & 239.57 & 206.28 & 139.93 & 288.73 & 40.55 & 30.07 & 12.03 & 35.19 & 217.58 & 126.11 & 57.33 & 123.01 \\
\hline $\operatorname{Adj} \mathrm{R}^{2}$ & 0.895 & 0.860 & 0.900 & 0.916 & 0.697 & 0.621 & 0.585 & 0.686 & 0.896 & 0.880 & 0.872 & 0.910 \\
\hline $\mathrm{N}$ & 1,720 & 769 & 339 & 612 & 903 & 392 & 165 & 346 & 817 & 377 & 174 & 266 \\
\hline
\end{tabular}


TABLE 7

The Impact of Marginal Audit Effort for Securitization on Accounting Manipulations

Panel A: Descriptive Statistics for Additional Variables in Equations (4) and (5)

(Other variables in Equations (4) and (5) are described in Table 3)

\begin{tabular}{lccc}
\hline Variable & Securitizers & Non- & Full sample \\
\hline RESTATEMENT & 0.093 & securitizers & 0.074 \\
SECGAIN & 0.006 & n.a. & \\
AFSEC & 0.001 & n.a. & 0.005 \\
LLP & 0.005 & 0.005 & 0.175 \\
M\&A & 0.205 & 0.115 & 0.037 \\
ICMW & 0.038 & 0.034 & -0.0000004 \\
SPECIALITEM & 0.000008 & -0.00001 & \\
PRE-SEC EARNINGS & 0.076 & n.a. & \\
\hline
\end{tabular}

Panel B: Distribution of Restatements

\begin{tabular}{lrrrr}
\hline Restatement type & \multicolumn{2}{c}{ GFC } & FAS166/167 & Total \\
\hline Irregularity & & & & \\
$\quad$ Non-securitizers & 25 & 8 & 15 & 48 \\
$\quad$ Securitizers & 85 & 23 & 21 & 129 \\
$\quad$ Total & 110 & 31 & 36 & 177 \\
Error & 12 & & 20 & 41 \\
$\quad$ Non-securitizers & 15 & 9 & 56 & 98 \\
$\quad$ Securitizers & 27 & 36 & 76 & 139 \\
$\quad$ Total & 37 & 17 & 35 & 89 \\
Total Restatements & 100 & 50 & 77 & 227 \\
$\quad$ Non-securitizers & 137 & 67 & 112 & 316 \\
$\quad$ Securitizers & & & \\
$\quad$ Total & & & & \\
\hline
\end{tabular}

Panel C: Restatement Logistic Regression Results - Full Sample

\begin{tabular}{|c|c|c|c|c|c|c|}
\hline \multirow{2}{*}{$\begin{array}{l}\text { Dependent variable } \\
\text { Variable }\end{array}$} & \multicolumn{2}{|c|}{ RESTATEMENT } & \multicolumn{2}{|c|}{$\begin{array}{l}\text { IRREGULARITY } \\
\text { (excluding ERROR) }\end{array}$} & \multicolumn{2}{|c|}{$\begin{array}{c}\text { ERROR } \\
\text { (excluding IRREGULARITY) }\end{array}$} \\
\hline & Coeff. & $\mathrm{p}$-value & Coeff. & $p$-value & Coeff. & p-value \\
\hline AFSEC & -528.553 & 0.035 & -636.956 & 0.084 & -273.623 & 0.353 \\
\hline $\mathrm{AFSEC} \times \mathrm{GFC}$ & 621.793 & 0.087 & 1199.433 & 0.011 & -51.766 & 0.912 \\
\hline AFSEC $\times$ FAS166/167 & 264.012 & 0.485 & 807.890 & 0.149 & -380.148 & 0.398 \\
\hline GFC & -0.828 & 0.034 & -1.841 & $<0.001$ & 0.317 & 0.584 \\
\hline FAS166/167 & -1.093 & 0.003 & -3.664 & $<0.001$ & 0.533 & 0.273 \\
\hline LOSS & 0.506 & 0.052 & -0.461 & 0.210 & 1.168 & $<0.001$ \\
\hline LNTA & 0.043 & 0.569 & 0.123 & 0.183 & -0.096 & 0.404 \\
\hline COMMLOAN & 1.323 & 0.120 & 0.851 & 0.419 & 2.010 & 0.065 \\
\hline INTANG & -7.946 & 0.075 & -13.972 & 0.051 & -2.951 & 0.610 \\
\hline INTDERIV & 0.043 & 0.048 & 0.050 & 0.033 & 0.044 & 0.189 \\
\hline CAPRATIO & 0.378 & 0.004 & 0.030 & 0.249 & 0.037 & 0.024 \\
\hline LLP & 21.297 & 0.013 & 49.802 & $<0.001$ & -0.079 & 0.995 \\
\hline M\&A & 0.240 & 0.256 & 0.435 & 0.070 & -0.022 & 0.945 \\
\hline ICMW & 1.904 & $<0.001$ & 2.766 & $<0.001$ & -0.089 & 0.872 \\
\hline SPECIALITEM & 87.197 & 0.155 & -91.134 & 0.066 & 346.349 & 0.015 \\
\hline BIGN & 0.706 & 0.003 & 0.669 & 0.032 & 0.738 & 0.040 \\
\hline Constant & -4.262 & 0.006 & -6.119 & 0.001 & -2.831 & 0.245 \\
\hline & 3,653 & & 3,514 & & 3,476 & \\
\hline Log pseudo likelihood & -957.510 & & -565.422 & & -524.376 & \\
\hline
\end{tabular}


Panel D: Securitization Gain Regressions - Securitizer Sample

\begin{tabular}{|c|c|c|c|c|c|c|}
\hline & \multicolumn{2}{|c|}{ Full sample } & \multicolumn{2}{|c|}{ Big N } & \multicolumn{2}{|c|}{ Non-Big N } \\
\hline Variable & Coeff. & p-value & Coeff. & p-value & Coeff. & p-value \\
\hline AFSEC & -5.061 & 0.056 & -7.277 & 0.055 & -1.178 & 0.616 \\
\hline $\mathrm{AFSEC} \times \mathrm{GFC}$ & 3.160 & 0.310 & 4.867 & 0.512 & 6.300 & 0.012 \\
\hline AFSEC $\times F A S 166 / 167$ & 4.190 & 0.064 & 5.191 & 0.204 & 2.879 & 0.149 \\
\hline GFC & -0.009 & 0.054 & -0.022 & 0.058 & -0.007 & 0.062 \\
\hline FAS166/167 & -0.011 & 0.021 & -0.020 & 0.023 & -0.005 & 0.206 \\
\hline PRE-SEC EARNINGS & -0.010 & 0.132 & -0.112 & 0.049 & -0.002 & 0.051 \\
\hline MARKET_VOLATILITY & 0.001 & 0.362 & 0.0001 & 0.700 & -0.0001 & 0.925 \\
\hline Constant - & 0.015 & 0.003 & 0.032 & 0.010 & 0.007 & 0.109 \\
\hline $\mathrm{n}$ & 2,406 & & 1,353 & & 1,053 & \\
\hline Adj $R^{2}$ & 0.033 & & 0.107 & & 0.017 & \\
\hline
\end{tabular}

Robust standard errors are clustered on BHCs in all regressions. Logistic regressions control for year fixed effects. The OLS regression does not control for year fixed effects because the period effects are collinear with year effects for SEC_GAIN. All $\mathrm{p}$-values are two-tailed. Variables are defined in Table 1. 